$$
\text { punto org }
$$

Collana diretta da Luigi Maria Sicca

78 


\author{
Barbara Czarniawska
}

\title{
PER UNA TEORIA DELL'ORGANIZZARE
}

\author{
Scritti di \\ Giuseppe Bonazzi Federico Butera \\ Francesco Piro Barbara Poggio Luigi Maria Sicca
}

Edizione italiana a cura di

Luigi Maria Sicca

Editoriale Scientifica

Napoli 
Il volume è stato realizzato con il contributo di

Dipartimento di Economia Management Istituzioni

Università degli Studi di Napoli Federico II

puntOorg International Research Network

\section{(C) Barbara Czarniawska}

Edizione originale: A Theory of Organizing, 2014; 2015.

Edward Elgar Publishing Limited The Lypiatts15 Lansdown Road

Cheltenham, Glos GL50 2JA, UK

Edward Elgar Publishing, Inc. William Pratt House

9 Dewey Court Northampton, Massachusetts 01060 USA

Edizione italiana a cura di Luigi Maria Sicca

Per una teoria dell'organizzare

Traduzione di Luigi Maria Sicca e Francesco Piro

Tutti i diritti sono riservati

(C) Copyright 2020 Editoriale Scientifica s.r.l.

Via San Biagio dei Librai, 39 - 80138 Napoli

www.editorialescientifica.com info@editorialescientifica.com

ISBN 978-88-9391-877-0 


\section{Indice}

9 Per una teoria dell'organizzare: prospettive per la comunità accademica italiana

Luigi Maria Sicca e Francesco Piro

21 1. Prospettiva: unA visione costruttivista DELL'ORGANIZZARE

$21 \quad 1.1$ Pluralità di costruttivismi

271.2 Il costruttivismo nella teoria dell'organizzazione: una proposta

$30 \quad 1.3$ Il costruttivismo e la pratica dell'organizzare: ci possono essere consulenti costruttivisti?

39 2. PUnto di PARTENZA: LA COSTRUZione E LA RicostruZione DELLE RETI D'AZIONE

392.1 Saggezza ereditata: modelli nella teoria dell'organizzazione

$45 \quad 2.2$ Sulle reti di azioni

$52 \quad 2.3$ La gestione della città come rete di azioni

552.4 Come vengono costruite e mantenute le reti di azioni all'interno dell'organizzare quotidiano

65 3. SULL'ORGANIZZAZIONE: NARRARE L'ORGANIZZAZIONE E ORGANIZZARE LE NARRAZIONI

$79 \quad 3.1 \quad$ Come gestire con le parole 
91 4. Sulla Stabilità: COME LE ISTITUZIONI Si INSCRIVONO IN OGGETTI TECNICI

94

94

99

103

108

113

113

115

116

121

121

126

130

133

133

136

139

143

146

4.1. Sabbie mobili: un alleato inaffidabile

4.1.1. Un'ontologia variabile: "Ora lo vedi, ora non lo vedi" 4.1.2 Il ritorno delle sabbie mobili

4.2 L'ambiente: Il verde e il rosso

4.3 Norme tecniche come inscrizioni istituzionali

5. Sulla CODifica: MOdAlità di GESTIONE DEgLi STRARIPAMENTI

5.1 La moltiplicazione dei codici

5.2 Codici nella vita di tutti i giorni

5.3 La codifica in guerra e la pace: servizi segreti, biblioteche e finanza

5.4 Agenzie di notizie: classificazione, categorie e codici 5.4.1 Codici, categorie e necessità di traduzione

5.5 Codificazione e interconnessione

5.6 La codifica come strumento per la gestione dei sovraccarichi

6. Sul MANAGEMENT: LA LEADERSHip COME SERVIZio

6.1 I dirigenti sono importanti?

6.2 Che tipo di dirigenti si possono trovare nelle organizzazioni professionali?

6.3 I leader per i nostri tempi

6.4 Leadership: un'impresa eroica o una gestione tranquilla?

6.5 Leadership nei media

6.6 Leadership nelle organizzazioni professionali del XXI secolo

7. SUl CAMBIAMENTO: È POSSIBILE SOLLEVARSI PER I CAPELLI?

7.1 Un sistema non può cambiare da solo

7.2 Perché, allora, questa costante riforma?

7.3 Tratti dannosi di molti cambiamenti pianificati

7.3.1 L'obiettivo della riforma viene reificato

7.3.2 Il mezzo (metodo) diventa il fine 
7.3.3 Le invenzioni spontanee vengono ignorate o respinte

$167 \quad 7.4$ La diffusione contro il modello di traslazione del cambiamento organizzativo

1707.5 Diffusione e traslazione: progetti contro riforme

172 Q 7.6 Quando alla traslazione è data libero sfogo ...

175 8. Sull' imitaZione E SUlla Moda: Come Le IDEE Viaggiano NEL MONDO

8.1 Sulle idee di viaggio

8.2 Locale-Globale: sulla glocalizzazione

8.3 Le grandi città sono divise tra l'essere locali e l'essere globali

8.4 La moda e la grande città

8.5 I paradossi della moda

8.6 Gestione della città e gestione in generale

9. Sul Genere: QUANTO È GLOBALE LA DisCRIMINAZIONE?

9.1. Imperialismo culturale

9.2. Donne professore ordinario

9.3 Le relazioni di genere negli USA come modello e criterio di valutazione

9.4 L'imperialismo culturale

9.5 Perché il locale non è abbastanza buono

10. Sulla VELOCitÀ e LA LENTEZZA: RicordARE E DiMENTICARE

10.1 La corsa delle notizie

10.2 Conseguenze della gara di notizie

10.3 Dove i nanosecondi contano: trading algoritmico 10.4 Veloce e lento

11. EPILOGO: ORGANIZZARE SENZA ORGANIZZAZIONI?

11.1 Organizzare tra organizzazioni

11.2 Le organizzazioni ostacolano l'organizzare

11.3 Alcuni postulati 
237 Postfazione: tavola rotonda

239 Narrare Barbara Czarniawska

di Giuseppe Bonazzi

247 Costruire le organizzazioni del futuro: processi e modelli di Federico Butera

253 Leggere Barbara Czarniawska in tempi di pandemia di Barbara Poggio

259 Bibliografia

277 Indice dei nomi

283 Hanno scritto nella Collana punto org 


\section{Per una teoria dell'organizzare: prospettive per la comunità accademica italiana}

Luigi Maria Sicca* e Francesco Piro**

puntOorg International Research Network (e la Collana punto org che ne è prevalente riferimento) si arricchisce di una preziosa perla con questo volume, manifestazione del pensiero e dell'operosità di Barbara Czarniawska. Non è la prima volta che realizziamo l'edizione italiana di un Classico della letteratura organizzativa. In fondo, il primo volume della Collana stessa, datato oramai 2010, raccoglieva alcuni testi proposti al pubblico italiano nella silloge Leggere e scrivere organizzazioni. Umanesimo, estetica e conoscenze manageriali, così come il volume 46, La narrazione nelle scienze sociali (ancora una volta della Czarniawska), seguito (su diverso registro teorico) da La Quinta Disciplina di Peter Senge (vol. 62) e altri sono in corso di realizzazione. Anche in questo caso proponiamo un gesto di traslazione, oltre che di traduzione, perché l'obiettivo non è soltanto fare conoscere al pubblico italiano un'opera che molti già hanno letto in inglese, ma di ambientare e mettere a regime un lessico e una griglia di ricerca

* Professore ordinario presso l'Università degli Studi di Napoli Federico II, insegna Organizzazione aziendale e Comportamento organizzativo. È Direttore scientifico di puntOorg International Research Network.

** Professore ordinario presso l'Università degli Studi di Salerno, insegna Storia della filosofia. In seno a puntOorg International Research Network è attivo su numerosi tavoli di ricerca, tra i quali si ricorda quello relativo al ruolo del pensiero critico come obiettivo didattico e come ambito di ricerca interdisciplinare. 
nel nostro Paese, riprendere e rivisitare il dibattito che il libro ha già suscitato, familiarizzare gli studenti con queste prospettive di ricerca fin dai primi anni, riconoscere insomma lo statuto di "classico" al testo.

In un momento storico in cui la nostra comunità sembra caratterizzata da una corsa a tratti furibonda verso la neophilia (complice anche la logica del $P_{o} P^{1}$, talvolta vero e proprio fucile puntato alla tempia dei ricercatori) e, specularmente, da una cultura neophobica alimentata, paradossalmente, proprio da un gusto sempre più spinto del (e per il) cinismo giovanilistico, recuperare alcuni fondamentali, in dialogo con le tendenze, a noi pare necessaria camera di compensazione: una preziosa riserva di pensiero, occasione per respirare e guardare avanti con fiducia alla dimensione più autentica dell'innovazione, a ciò che realmente può essere tale, senza paura perché con spalle forti e solide.

È con questo spirito che si propone oggi la prima edizione italiana di Per una teoria dell'organizzare: un testo che ha fecondato generazioni di studiosi - forte di una lunga e articolata gestazione $^{2}$ - attraverso un accorto e pregnante intreccio (plot) di sguardi epistemologici e teorici cui noi di puntOorg guardiamo, da sempre, con interesse. Fino a fare di questo modo di intendere l'organizzare uno sguardo sul mondo, una Weltanschauung, di cui possono beneficiare non solo le organizzazioni aziendali (in fondo recenti, appena centenari contenitori della maggior parte del tempo della nostra vita adulta), ma ogni altro contenitore che

1 Come si vedrà nel capitolo 10 di questo volume, Publish or perish" (PoP) - "Pubblicare o morire" - è al contempo acronimo e aforisma che descrive la pressione a pubblicare il lavoro accademico per avere successo di carriera, con possibili e non poche ripercussioni in termini di effetti distorsivi, laddove si assista a una manifestazione reale del rischio associato a dinamiche di inversione del rapporto mezzi-fini.

2 L'autrice riprende e sistematizza molte delle idee presentate, in nuce, in suoi precedenti lavori pionieristici. 
da forma, rassicura e contiene (appunto) le ansie infantili e più arcaiche che ciascuno di noi porta anche nel presente, regolando in ultima analisi la convivenza ${ }^{3}$.

Il libro di Barbara Czarniawska che il lettore ha davanti a sé nasce all'insegna di una doppia scelta teorica (di qui il titolo: A theory, per sottolineare che le scelte sono molte e nessuna può essere scartata a priori):

(1) adottare un approccio costruttivistico (o "costruzionisti$\mathrm{co}^{\prime \prime}$, come Czarniawska suggerisce di scrivere) alle scienze sociali e

(2) intendere il costruttivismo /costruzionismo come uno sguardo interpretativo che privilegia la dimensione dei processi su quella delle strutture o che, per meglio dire, preferisce considerare queste ultime come reti di azioni interdipendenti e non come schemi di relazione rigidi e fissati una volta per tutte.

La seconda scelta - che qualifica la prima e le conferisce il suo significato più profondo - è adombrata fin dal titolo che, ispirandosi a K. Weick, preferisce parlare di Organizing (organizzare, attività organizzante) piuttosto che di Organization(s).

Queste linee di una possibile teoria dell'organizing sono radicate in una lunga tradizione di studi (in particolare di sociologia e antropologia delle organizzazioni) di cui Czarniawska fa in questo libro anche una breve storia, a beneficio di chi è meno addentro a questa letteratura e che dovrebbe quindi ripercorrerla autonomamente $\mathrm{o}$, viceversa, addetto ai lavori e che potrà quindi ritrovarsi, attraverso le esperienze maturate negli anni dall'autrice stessa.

Ma Barbara Czarniawska non si limita a proseguire una tradizione che privilegia la dimensione pragmatica, storico-contestuale, fluida, della vita sociale su ipotetiche catene causali rigide e nessi strutturali immodificabili (una sociologia di impostazione

3 Per un approfondimento sulle organizzazioni come "contenitori d'ansia”, si rinvia a Sicca, L.M. (2016), "Diversity management, inclusione, analisi organizzativa. Spunti, punti e appunti”, Prospettive in Organizzazione, n. 4. 
pragmatistica e - noi oseremmo dire -"storicistica", se questo non viene preso come un ossimoro). La studiosa ne ricava due ulteriori e fondamentali sviluppi che questo libro schizza, in modo chiaro e talora quasi provocatorio.

Il primo di questi sviluppi dipende dal fatto che Barbara legge non l'azione come comunicazione (cioè come processo di informazione), secondo la linea luhmanniana, ma - soprattutto la comunicazione come azione, ovvero come processo di costruzione e istituzione di reti di rapporti e vincoli tra agenti (o come vedremo "attanti"), ispirandosi alla teoria degli atti linguistici. In particolare, ciò vale per una specifica (ma diffusissima) forma di comunicazione, che è il narrare, il fare resoconti, che l'autrice ci aveva già indicato in La narrazione nelle scienze sociali - proposto ai lettori di puntOorg nel precedente progetto del 2018 - e su cui torna anche in questo libro. In quella sede, sulla scia di Ricoeur, Bruner, Hayden White, Alisdair MacIntyre e tanti altri autori, Czarniawska ne discuteva distesamente analizzando le relazioni tra l'atto di narrare e la costituzione di determinati schemi di relazione tra Sé e l'Altro, dunque schemi di auto-identificazione da parte di singoli e di organizzazioni. Ma questo tema, molto efficace per l'indagine etnografica e per l'uso sapiente di interviste e altri strumenti di ricerca, è in Czarniawska sempre correlato a una consapevolezza del fatto che non esiste narrazione esclusiva, ovvero non esistono comunità in cui la narrazione dominante non sia sfidata o almeno interrotta da narrazioni non dominanti.

E di qui deriva il secondo e fondamentale snodo teorico di questo libro, perché l'immagine della vita organizzativa come una realtà complessa e mutevole veicola un preciso messaggio critico nei confronti dell'ideologia delle "riforme dall'alto", della pianificazione del cambiamento organizzativo, nonché della concezione prometeica della direzione (leadership) e della gestione organizzativa (management) che proprio questa ideologia comporta. Una denuncia a favore del riconoscimento di eccezioni, imprevisti e dello straordinario che sanno assurgere a lente di ingrandimento, a 
microscopio ${ }^{4}$ in grado di rendere visibili questioni fondamentali, tenuti in ombra in tempi e contesti considerati "ordinari" o "normali". Lo abbiamo sotto gli occhi in questo difficile 2020 durante il quale si stanno ulteriormente frammentando le relazioni (interumane, ma anche industriali), private della quotidiana marca artefattuale (fatto ad arte; effetto dell'arte; quindi di una conoscenza mediata dai sensi): questo stato di cose, considerato (a torto o a ragione) eccezionale, imprevisto e straordinario, getta luce su quanto la "rete di azioni" sia un costrutto (da sempre e) sempre più adeguato a cogliere l'essenza non lineare del nostro stare insieme, mentre al contrario quanto artificiosa sia (sempre stata) la definizione del concetto di "confine organizzativo" e il correlato di "organizzazione", tipico di quei momenti storici scanditi da certezze e crescita economica continua. Si tratta senza sconti di costrutti deboli e scarsamente aderenti alla realtà, al cospetto della evidente dilatazione dei tempi e degli spazi di lavoro, senza confini appunto, con conseguenti variazioni nei ritmi della produttività pro capite, misurata sul lavoro on line: smartworking, telelavoro, comunque connessioni a distanza h. 24 e così via. D'altra parte, i capitoli centrali di questo libro colgono con ironia i paradossi del "tirarsi per il proprio codino", caro al Barone di Münchhausen, celato dietro l'immagine dell'organizzazione come sistema autopoietico, per mostrare che in realtà l'organizzazione (pardon, la "rete di azioni" istituzionalizzata che noi chiamiamo organizzazione) non è un sistema che si autogestisce, ma un complicato insieme di processi simbiotici in reciproco adattamento, così che ogni cambiamento ha quasi di necessità esiti diversi da quelli inizialmente previsti e di cui bisogna tenerne conto, magari per cambiare egualmente, ma lasciando spazio per l'imprevisto e per ciò che diverge dallo schema iniziale.

4 Sicca, L.M. (2000), Chamber Music and Organization Theory: Some Typical Organizational Phenomena Seen Under The Microscope», Culture and Organization, 6(2): 145-169. 
Ed ecco che il libro si configura non solo come un trattato ricco di strumenti teorici e proposte metodologiche per i ricercatori che studino le organizzazioni (pardon, l'organizzare), ma anche - implicitamente - come una sana guida a una concezione più saggia e più umana dell'esercizio di ruoli direttivi e a una cultura della gestione molto diversa da quella attuale: cioè a due temi a cui puntOorg International Research Network è sensibile fin dalla sua costituzione. Certamente Barbara Czarniawska ha tanto da dire su come si possono studiare le organizzazioni, ma appare meno interessata a come si deve organizzare, perché ciò implicherebbe l'assunzione (cui l'autrice non crede) di ricette universali. E tuttavia questa seconda esigenza è implicita nel modo in cui Czarniawska sviluppa il suo discorso.

Sottolineiamo questo spaccato teorico profondo, inevitabilmente foriero di implicazioni nella realtà sensibile, perché è importante non cadere in errori prospettici da cui i primi capitoli meritoriamente ci mettono in guardia: il costruttivismo o costruzionismo non è tanto una premessa filosofica a se stante, quanto un punto di vista grazie al quale si può tener conto di ciò che altrimenti non si osserverebbe e, cioè, l'infinita serie di impliciti e di presupposti pratici su cui vive l'apparente linearità della vita organizzativa.

Nella versione di Czarniawska, il costruzionismo non implica dunque né contrapporre la realtà sociale a quella naturale - non significa nemmeno affermare che i fatti non ci sono semplicemente perché è evidente che la constatazione di essi è sempre carica di teoria - né significa essere più vicini all'idealismo che al realismo.

Non certo digiuna dei dibattiti filosofici su questi temi e delle diverse varietà del pragmatismo americano (da Rorty a Putnam), che sono una delle fonti di ispirazione insieme con i neostoricismi di impianto narratologico (Hayden White, Alisdair MacIntyre, ovviamente sullo sfondo Paul Ricoeur), Barbrara non ci spinge a prendere una posizione metafisica, ma a costruire un modello teorico che possa fungere da strumentario per la ricerca. 
La scelta costruttivistica o costruzionistica è, insomma, quella di vedere la realtà organizzativa (e sociale in genere) come un farsi (ing, gerundio) piuttosto che come un fatto (participio passato del verbo all'infinito), senza con ciò negare che vi siano anche processi irreversibili o vincoli strutturali dell'agire organizzativo, sebbene la considerazione dinamica sia ovviamente finalizzata a cogliere ciò che è ancora emendabile (trasformabile) in questi processi piuttosto che ciò che resta inemendabile, riprendendo in tal senso la terminologia di Maurizio Ferraris. Ma i due poli convivono in ogni analisi, che non è mai una ricostruzione dal nulla del proprio oggetto.

All'atteggiamento costruzionistico che connota Per una teoria dell'organizzare, appartiene anche una scelta che privilegia l'azione sull'agente, vedendo anche quest'ultimo in una logica costruttivistica e non come un soggetto che bisogna presumere come già dato. In sintesi, per Czarniawska noi possiamo guardare le organizzazioni come reti di azioni e dunque mettere in risalto il fatto che gli individui (le persone) ne sono costantemente il supporto e sono loro, le loro decisioni, il loro modo di auto-identificarsi e di auto-riconoscersi a essere la realtà concreta che c'è dietro la fittizia entità "organizzazione". Ma poi si può anche cambiare prospettiva, senza rinchiudersi nel ghetto dell'individualismo metodologico, vedendo le persone non come portatori naturali di ruoli e di scelte, ma come entità costantemente modificate dalle idee che circolano e dalle narrazioni a cui partecipano, raccontando dunque i processi di innovazione come processi con cui si afferma (replicandosi in mille varianti) un'idea, piuttosto che come una serie di atti decisionali di persone.

Pur tenendosi lontana dalle teorie biologizzanti sui "memi" come micro-organismi informazionali che transitano da un cervello a un altro o dalle teorie sul contagio delle idee à la Sperber, Barbara Czarniawska affronta in questo libro il problema della diffusione delle idee senza dare per scontato come esso sia un processo di imitazione, secondo lo schema di Tarde, ma met- 
tendo in una correlazione circolare i processi di diffusione delle idee, variazione delle idee, costituzione degli attori che agiranno sulla base di tali idee.

Come già nei lavori sulla narrazione, l'autrice si richiama in questo contesto alla "teoria degli attanti" di Greimas. Gli "attori" non sono soggetti essenzialmente predestinati a svolgere il ruolo di centro della scena, ma il risultato di un processo di selezione all'inizio del quale vi sono molti pretendenti al ruolo di centro della storia: gli attanti appunto, indipendentemente se si tratti di esseri umani, di oggetti tecnici, di meri oggetti narrativi.

Per dirla facile, il costruttivismo di Czarniawska non è un ulteriore frutto di quella grande tradizione umanistica che vuole sottolineare che noi, le persone, siamo quelli che veramente danno senso al mondo, che ne siamo i "soggetti" e che sarebbe una "alienazione" se ci facessimo determinare, nei nostri comportamenti, dagli "oggetti". Al contrario, l'autrice sottolinea l'importanza che determinati oggetti tecnologici hanno nell'organizzare le nostre vite, l'impossibilità di prescindere dalle loro funzioni proprie (e non solo da quelle estetico-simboliche) quando esaminiamo come si stabilizzano le reti di azione tra gli umani. Morale:

Gli esseri umani non sono "ingranaggi" in questa macchina, non più di quanto non siano i chip nei loro computer. Hanno costruito questa macchina - questo strumento - con l'aiuto di altri co-costruttori (quindi "costruzione sociale"), ma, una volta costruita, la macchina continua a costruire i suoi costruttori., p. 233.

Il modo per evitare la "reificazione" delle organizzazioni sta dunque nel valutare come una data macchina può funzionare in modi alternativi (il "ritorno" di una macchina, cioè $i$ suoi usi potenziali, è sempre più alto di quello che il costruttore può vedere o progettare) ed è qui che il ricercatore (o il consulente) costruttivista può essere prezioso. In breve, la metafora meccanicistica così ben presente in "costruzione" viene piegata da Czarniawska in un senso peculiare, che quasi ne inverte il 
senso: processo di aggregazione, di reazione molecolare e diffusa alle novità, di selezione di un numero di possibilità sempre più vasto di quelle che consideriamo esplicitamente. Si tratta di uno schema di descrizione delle realtà organizzate/organizzantisi che senz'altro dialoga con le forme più avanzate di teoria della complessità, ma che è soprattutto calata in una esperienza diretta e continuativa di come le organizzazioni aziendali e le istituzioni tutte prendono decisioni, ovvero innescano processi di deliberazione collettiva. Esemplari sono al proposito le pagine dedicate ad aziende e istituzioni (in particolare Comuni) che ci fanno vedere dall'interno come si svolgono (e come spesso falliscono) processi di riforma organizzativa innescati dall'alto. E proprio queste pagine consiglieremmo molto a quanti leggeranno questo libro in qualità di impegnati protagonisti di processi organizzativi (nel linguaggio odierno, in senso lato, stakeholder), perché appunto in tali pagine si rileva anche quell'invito alla saggezza e quell'intento di portare l'organizzatore a comprendere i limiti della propria attività organizzativa di cui si discuteva poche righe fa.

E questo invito ci appare decisivo soprattutto oggi. Mentre scriviamo queste pagine, stiamo attraversando il guado di una pandemia dal futuro imprevedibile (unica certezza è che, ancora una volta, la dilatazione delle fasi di crisi a dispetto della rassicurante crescita, guardando retrospettivamente a partire dal 1929-1973-1991-2008-2020) $)^{5}$ e siamo alla vigilia dell'ingresso massiccio nelle nostre vite del $5 \mathrm{G}$ che, per quanto

5 https://www.puntoorg.net/index.php/it/. È proprio alla luce delle non opportunità di contrapporre la realtà sociale a quella naturale di cui sopra, come di avverte la Czarniawska sin dai primi capitoli, che non vale distinguere tra le crisi del Novecento - fino (inclusa) quella del 2008 - come $d i$ cultura, a carattere industriale e finanziario e l'ultima, del 2020, come di natu$r a$, perché attivata da un salto di specie. Si veda, in chiave divulgativa, Sicca, L.M. (2020), "Perché questa crisi non è (tanto) diversa dalle precedenti", Le parole di management, Sabato 20 maggio; "La crisi è forte, ma la produzione crescerà", La Repubblica, Venerdì 29 maggio: 22. 
siamo oggi in grado di comprendere davvero, modificherà ancora una volta gli assetti dello spazio-tempo nelle nostre menti, attraverso il travaso (ma anche traduzione e traslazione) di una scoperta dalla scienza astratta alla tecnica, generandone quindi

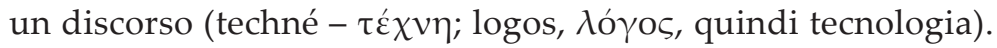
È importante saper guardare a questi processi senza sottovalutare il modo in cui il mutamento di tecnologia cambia l'attività organizzativa e le forme di relazioni interpersonali, ma anche senza vedere tale mutamento come unilineare o come solutore di tutti i problemi.

Come ogni proposta di una teoria, questo testo presenta un proprio lessico di cui occorre dare una plausibile traduzione in italiano. Alcuni termini sono già presenti in Czarniawska, Rhodes "Trame forti: la cultura di massa nella teoria e nella pratica del management" ([2006] 2010) e in La narrazione nelle scienze sociali ([2004] 2018). Ci limitiamo quindi a riprendere la traduzione/traslazione da noi proposta in quella sede e, analogamente, procederemo per tutto quanto già tradotto in italiano, che il lettore troverà nella bibliografia finale corredata anche dai nomi dei traduttori di ciascuna delle opere riportate. Su alcuni passaggi più delicati, specie laddove abbiamo riscontrato scivolosità semantiche e interpretative, segnaleremo necessari chiarimenti con una Nota dei traduttori [N.d.T.].

Grazie al Dipartimento di Economia Management Istituzioni dell'Università degli Studi di Napoli Federico II per avere contribuito a realizzare questa pubblicazione e per avere ospitato, in partnership con il Dipartimento di Scienze sociali del nostro Ateneo, la prof.ssa Czarniawska per un visiting nell'autunno 2019. Occasione feconda per arricchire la circolazione delle idee, su scala internazionale, con il coinvolgimento di studenti, studiosi, docenti e ricercatori di Università e centri di ricerca.

Grazie a Giuseppe Bonazzi, Federico Butera e Barbara Poggio per avere accettato l'invito a commentare il testo con una nota in Postfazione, intorno a una virtuale Tavola rotonda: una 
metodologia oramai consolidata nei nostri progetti ${ }^{6}$ per generare un caleidoscopio di prospettive intorno al pensiero dell'autrice. In fondo ogni ricerca, quindi anche questa ben consolidata tra gli studiosi di organizzazioni è, sì, il punto di arrivo di chi la propone, ma anche punto di partenza per riflessioni ulteriori, occasione di rilancio, attraverso gli occhi dei lettori interessati (cui è affidato, à la Geertz, il compito di interpretare le interpretazioni) e degli autorevoli colleghi che hanno contribuito a dilatare il cristallino attraverso cui leggere e rileggere.

Grazie naturalmente a Barbara Czarniawska stessa, per avere approvato tutti i cambiamenti apportati rispetto all'originale. Ma soprattutto per averci ispirato, attraverso il suo scritto, a cimentarci ancora una volta con il mestiere del traduttore, pardon del tradurre e del traslare: viaggio divertente, temprante e formativo.

18 agosto 2020

Luigi Maria Sicca Napoli, Università degli Studi Federico II

Francesco Piro Salerno, Università degli Studi

6 Si rinvia al numero 8 della Collana, Aa.Vv. (a cura di L.M. Sicca) (2013), Tavola rotonda, Napoli, Editoriale scientifica, che rilanciava il dibattito sollevato nel n. 1. Impostazione seguita poi, sistematicamente, in molti altri lavori e in tutte le altre prime edizioni in italiano. 



\section{Bibliografia}

Abbott, Andrew (1988), The System of Professions, Chicago, IL, University of Chicago Press.

Acker, Joan (2008), "Helpful men and feminist support: more than double strangers", Gender, Work \& Organization, 15(3), 288-93.

Adolfsson, Petra (2005), “Environment's many faces: on organizing and translating objects in Stockholm", in Barbara Czarniawska and Guje Sevón (eds), Global Ideas: How Ideas, Objects and Practices Travel in Global Economy, Malmö, Liber, 94-105.

Ahrne, Göran and Brunsson, Nils (2011), “Organization outside organizations: the significance of partial organization", Organization, 18(1), 83-104.

Alvesson, Mats (2003), "Critical organization theory", in Barbara Czarniawska and Guje Sevón (eds), The Northern Lights - Organization Theory in Scandinavia, Malmö, Liber, 151-74.

Alvesson, Mats and Yvonne Due Billing ([1997] 2009), Understanding Gender and Organizations, London, Sage.

Ancori, Bernard, Antoine Bureth and Patrick Cohendet (2000), "The economics of knowledge: the debate about codification and tacit knowledge", Industrial and Corporate Change, 9(2), 255-87.

Arnold, Thurman Wesley (1937), The Folklore of Capitalism, Westport, CT, Greenwood Press.

Aronson, Elliot (1972), The Social Animal, New York, NY, Viking.

Austin, John L. (1962), How to Do Things With Words, New York, NY, Oxford University Press Sage [tr. it. 2017, di C. Villata, a cura di M. Sbisà, C. Penco, Come fare cose con le parole, Bologna, Marietti].

Badham, Richard, Karin Garrety, Vivianne Morrigan, Michael Zanko and Patrick Dawson (2003), “Designer deviance: enterprise and deviance in culture change programmes", Organization, 10(4), 707-30. 
Bailyn, Lotte (2008), "Hierarchy of strangers: negating womanhood", Gender, Work \& Organization, 15(3), 294-7.

Bauman, Zygmunt (2003), Razem osobno, Kraków, Wydawnictwo Literackie [tr. it. 2008, di R. Capovin, P. Costa, V. Annicchiarico, a cura di in C. Leccardi, Individualmente insieme, Parma, Diabasis].

Bauman, Zygmunt (2005), Liquid Life, Cambridge-Oxford-Boston, Polity [tr. it. 2006, di M. Cupellaro, Vita liquida, Roma-Bari, Laterza].

Becker, Howard S. (1966), Outsiders: Studies in Sociology of Deviance, New York, NY, Free Press [tr. it. 2017, di C. Vuadens, M. Croce, D. Brignoli, Outsiders. Studi di sociologia della devianza, Milano, Meltemi]. Benschop, Yvonne and Margo Brouns (2003), “Crumbling ivory towers. Academic organizing and its gender effects", Gender, Work \& Organization, 10(2), 194-212.

Berger, Peter and Thomas Luckmann (1966), The Social Construction of Reality, New York, NY, Doubleday [tr. it. e a cura di 1969, di M. Sofri Innocenti, La realtà come costruzione sociale, Bologna, Il Mulino].

Billig, Michael (2013), Learn to Write Badly. How to Succeed in the Social Sciences, Cambridge, Cambridge University Press.

Blumer, Herbert G. (1969), “Fashion: from class differentiation to collective selection", Sociological Quarterly, 10(3), 275-91 [tr. it. 2008, "Moda: da differenziazione di classe a selezione collettiva", in C. Baldini (a cura di), Sociologia della moda, Roma, Armando editore, 1-16].

Bonazzi, Giuseppe (1999), Dire fare pensare: decisioni e creazione di senso nelle organizzazioni, Milano, Franco Angeli.

Borges, Jorge Luis ([1935] 1954), Historia universal de la infamia, Buenos Aires, Editorial Tor [tr. it. 1961, di M. Pasi, Storia universale dell'infamia, Milano, Il Saggiatore].

Bourdieu, Pierre (1980), Le Sense practique, Paris, Les Éditions de Minuit [tr. it. e cura di 2005, di M. Piras, Il senso pratico, Roma, Armando editore].

Bourdieu, Pierre and Wacquant, Loic (1999), “On the cunning of imperialist reason", Theory, Culture and Society, 16(1), 41-58 [tr. it. 2005, di A. De Giorgi, S. De Petris, "Le astuzie della ragione imperialista", in L. Wacquant (a cura di), Le astuzie del potere. Pierre Bourdieu e la politica democratica, Verona, Ombre Corte, 161-178].

Bowker, Geoffrey C. (2006), Memory Practices in the Sciences, Cambridge, MA, MIT Press. 
Bowker, Geoffrey C. and Susan Leigh Star (1999), Sorting Things Out. Classification and Its Consequences, Cambridge, MA, MIT Press.

Brett, Simon (1991), Corporate Bodies, London, Golancz.

Brose, Hans-Georg (2004), "Introduction. Towards a culture of nonsimultaneity?", Time and Society, 13(1), 5-26.

Bruner, Jerome (1986), Actual Minds, Possible Worlds, Cambridge, MA, Harvard University Press [tr. it. 1993, di R. Rini, La mente a più dimensioni, Roma-Bari, Laterza].

Brunsson, Nils (1982), "The irrationality of action and action rationality: decisions, ideologies and organizational actions", Journal of Management Studies, 19(1), 29-44.

Brunsson, Nils (1989), The Organization of Hypocrisy, Chichester, John Wiley.

Brunsson, Nils (1993), "Reforms as a routine", in Nils Brunsson and Johan P. Olsen (eds), The Reforming Organization, London, Routledge, 33-47.

Brunsson, Nils and Bengt Jacobsson (2000), A World of Standards, Oxford, Oxford University Press.

Brunsson, Nils and Johan P. Olsen (eds) (1993), The Reforming Organization, London, Routledge.

Burns, Tom and G.M. Stalker ([1961] 1996), The Management of Innovation, Oxford, Oxford University Press.

Butera, F. (2020), Organizzazione e società, Innovare le organizzazioni per l'Italia che vogliamo, Venezia, Marsilio.

Callon, Michel (1998), "An essay on framing and overflowing: economic externalities revisited by sociology", in Michel Callon (ed.), The Laws of the Markets, Oxford, Blackwell, 244-69.

Candea, Matei (ed.) (2010), The Social After Gabriel Tarde. Debates and Assessments. Abingdon, Routledge.

Carlson, Sune ([1951] 1991), Executive Behaviour, with contributions by Henry Mintzberg and Rosemary Stewart, Uppsala, Acta Universitatis Upsaliensis, 32.

Case, Peter, Simon Lilley and Tom Owen (eds) (2006), The Speed of Organization, Malmö/Copenhagen, Liber/CBS Press.

Chaboud, Alain, Benjamin Chiquoine, Erik Hjalmarsson e Clara Vega (2014), "Rise of the machines: algorithmic trading in the foreign exchange market", Journal of Finance, 69(5), 2045-2084.

Clegg, Stewart R., Stephen Linstead and Graham Sewell (2000), “Only penguins: a polemic on organization theory from the edge of the world", Organization Studies, 21(0), 103-17. 
Cohendet, Patrick and W. Edward Steinmueller (2000), “The codification of knowledge: a conceptual and empirical exploration", Industrial and Corporate Change, 9(2), 195-209.

Connerton, Paul (1989), How Societies Remember, Cambridge, Cambridge University Press [tr. it. 1999, di G. Berno, Come le società ricordano, Roma, Armando Editore].

Corvellec, Hervé (2001), "The new rhetoric of infrastructure projects", in Barbara Czarniawska and Rolf Solli (eds), Organizing Metropolitan Space and Discourse, Malmö, Liber, 192-209.

Cowan, Robin, Paul A. David and Dominique Foray (2000), “The explicit economics of knowledge codification and tacitness", Industrial and Corporate Change, 9(2), 211-53.

Cowan, Ruth Schwartz (1985), More Work for Mother: The Ironies of Household Technology from the Open Hearth to the Microwave, New York, NY, Basic Books.

Czarniawska, Barbara (1997), Narrating the Organization. Dramas of Institutional Identity, Chicago, IL, University of Chicago Press [tr. it. 2000, di L. Morra, Narrare l'organizzazione. La costruzione dell'identità istituzionale, Roma, Edizioni di Comunità].

Czarniawska, Barbara (2000), A City Reframed. Managing Warsaw in the 1990s, Reading, Harwood Academic Publishers.

Czarniawska, Barbara (2001a), "Anthropology and organizational learning", in Meinholf Dierkes, Ariane Berthoin Antal, John Child and Ikuijro Nonaka (eds), Handbook of Organizational Learning and Knowledge, Oxford, Oxford University Press, 118-36.

Czarniawska, Barbara (2001b), "Is it possible to be a constructionist consultant?", Management Learning, 32(2), 253-72.

Czarniawska, Barbara (2002), A Tale of Three Cities, or the Glocalization of City Management, Oxford, Oxford University Press.

Czarniawska, Barbara (2003), "Social constructionism and organization studies", in Robert Westwood and Stewart Clegg (eds), Debating Organization. Point- Counterpoint in Organization Studies, Oxford, Blackwell, 128-39.

Czarniawska, Barbara (2004a), "On time, space and action nets", Organization, 11(6), 777-95.

Czarniawska, Barbara (2004b), “Metaphors as enemies of organizing, or the advantages of a flat discourse", International Journal of Sociology of Language (166), 45-65. 
Czarniawska, Barbara (2004c), Narratives in Social Science Research, London, Sage [tr. it. e a cura di 2018, L.M. Sicca, F. Piro, I. Boncori, La narrazione nelle scienze sociali, Napoli, Editoriale scientifica].

Czarniawska, Barbara (2005), “Networks, networking and nets: NCW from an organization theory perspective", in Karl Ydén (ed.), Directions in Military Organizing, Stockholm, Försvarshögskolan, 63-88.

Czarniawska, Barbara (2008), "Accounting and gender across times and places", Accounting, Organizations and Society, 33(1), 33-47.

Czarniawska, Barbara (2009) ANSA: Analisi etnografica di un'agenzia di stampa, Milano, Carocci.

Czarniawska, Barbara (2010a), "Going back to go forward: on studying organizing in action nets", in Tor Hernes and Sally Maitlis (eds), Process, Sensemaking and Organizing, Oxford, Oxford University Press.

Czarniawska, Barbara (2010b), “Translation impossible? Accounting for a city project", Accounting, Auditing and Acountability Journal, 23(3), 420-437.

Czarniawska, Barbara (2011), Cyberfactories. How News Agencies Produce News, Northampton, MA, USA and Cheltenham, UK, Edward Elgar.

Czarniawska, Barbara (2012), "New plots are badly needed in finance: accounting for the financial crisis of 2007-2010", Accounting, Auditing and Accountability Journal, 25(5), 756-75.

Czarniawska, Barbara (2013), "Negotiating selves: gender at work”, Tamara Journal for Critical Organization Inquiry, 11(1), 59-72.

Czarniawska, Barbara and Orvar Löfgren (eds) (2019), Overwhelmed by Overflows?: How People and Organizations Create and Manage Excess, Lund, Lund University Press.

Czarniawska, Barbara and Kristina Genell (2002), “Going shopping? Universities on their way to the market", Scandinavian Journal of Management (18), 455-74.

Czarniawska, Barbara and Tor Hernes (eds) ([2005] 2020), Actor- Network Theory and Organizing, Lund, Studentlitteratur.

Czarniawska, Barbara and Bengt Jacobsson (1995), "Politics as commedia dell'arte", Organization Studies, 16(3), 375-94.

Czarniawska, Barbara and Bernward Joerges (1995), "Winds of organizational change. How ideas translate into objects and actions", in 
Samuel Bacharach, Pasquale Gagliardi and Brian Mundell (eds), Research in the Sociology of Organizations, vol. 13, Greenwich, CT, JAI Press, 171-209 [tr. it. 1995, "Venti di cambiamento organizzativo. Come le idee si traducono in oggetti e azioni", in P. Bacharach, P. Gagliardi, B. Mundell (a cura di), Il pensiero organizzativo europeo, Milano, Guerini e Associati, 213-255].

Czarniawska, Barbara and Bernward Joerges (1996), “Travels of ideas", in Barbara Czarniawska and Guje Sevón (eds), Translating Organizational Change, Berlin, de Gruyter, 13-48.

Czarniawska, Barbara and Orvar Löfgren (eds) (2012), Managing Overflow in Affluent Societies, New York, NY, Routledge.

Czarniawska, Barbara and Orvar Löfgren (eds) (2013), Coping with Excess: How Organizations, Communities and Individuals Manage Overflow, Northampton, MA, USA and Cheltenham, UK, Edward Elgar.

Czarniawska, Barbara and Orvar Löfgren (eds) (2019) Overwhelmed by Overflows? How People and Organizations Create and Manage Excess. Lund, Lund University Press, OA.

Czarniawska, Barbara and Carmelo Mazza (2003), “Consulting as liminal space", Human Relations, 56(3), 267-90.

Czarniawska, Barbara and Carl Rhodes (2006), "Strong plots. The relationship between popular culture and management theory and practice", in Pasquale Gagliardi and Barbara Czarniawska (eds), Management Education and Humanities, Northampton, MA, USA and Cheltenham, UK, Edward Elgar, 195-218 [tr. it. 2010, “Trame forti: la cultura di massa nella teoria e nella pratica del management", in L.M. Sicca (a cura di), Leggere e scrivere organizzazioni. Estetica, umanesimo e conoscenze manageriali, Napoli, Editoriale scientifica, 91-130].

Czarniawska, Barbara and Guje Sevón (1996), "Introduction", in Barbara Czarniawska and Guje Sevón (eds), Translating Organizational Change, Berlin, de Gruyter, 1-12.

Czarniawska, Barbara and Guje Sevón, (2008), "The thin end of the wedge: foreign women professors as double strangers in academia", Gender, Work \& Organization, 15(3), 235-87.

Czarniawska, Barbara and Rolf Solli (eds) (2001), Organizing Metropolitan Space and Discourse, Malmö/Oslo, Liber/Abstrakt. 
Czarniawska, Barbara, Carmelo Mazza e Tatiana Pipan (2001), Gestire grandi citta. Storie di Roma al passaggio del millennio, Milano, FrancoAngeli.

Czarniawska- Joerges, Barbara (1989), Economic Decline and Organizational Control, New York, NY, Praeger.

Czarniawska- Joerges, Barbara ([1993] 2006), The Three- dimensional Organization: A Constructionist View, Lund, Studentlitteratur.

Darnton, Robert (2000), "Paris: the early internet", New York Review of Books, 47.

Davies, Norman (2012), Vanished Kingdoms, London, Penguin.

DePamphilis, Donald (2008), Mergers, Acquisitions, and Other Restructuring Activities, New York, NY, Elsevier.

Devoto, Giacomo, Oli, Gian Carlo, (1971), Vocabolario della lingua italiana, Firenze, Le Monnier.

Diamond, Jared (1997), "The curse of Qwerty", Discover, 4 January.

Diedrich, Andreas (2004), Engineering Knowledge: How Engineers and Managers Practice Knowledge Management, Gothenburg, BAS.

Dobers, Peter (2002), "Broadband - boom and bust in the new economy", in Ingalill Holmberg, Miriam Salzer- Mörling and Lars Strannegård (eds), Stuck in the Future. Tracing the 'New Economy', Stockholm, Bookhouse, 79-104.

Eco, Umberto (2003), Dire quasi la stessa cosa. Esperienze di traduzione, Milano, Bompiani.

Eriksen, Thomas Hylland (2006), “Diversity versus difference: Neoliberalism in the minority- debate", in Richard Rottenburg, Burkhard Schnapel and Shingo Shimada (eds), The Making and Unmaking of Differences, Bielefeld, Transcript, 13-26.

Eriksson, Ulla (2002), "Construction of gender in corporations", in Barbara Czarniawska and Heather Höpfl (eds), Casting the Other. The Production and Maintenance of Inequalities in Organizations, London, Routledge, 89-103.

Erlingsdottir, Gudbjörg and Kajsa Lindberg (2005), “Isomorphism, isopraxism and isonymism: complementary or competing or processes?", in Barbara Czarniawska and Guje Sevón (eds), Global Ideas: How Ideas, Objects and Practices Travel in Global Economy, Malmö, Liber, 47-7.

Feldman, Martha S. and Kaj Sköldberg (2002), "Stories and the rhetoric of contrariety: subtexts of organizing (change)", Culture \& Organization, 8(4), 275-92. 
Fiedler, Fred E. (1967), A Theory of Leader Effectiveness, New York, NY, McGraw- Hill.

Florida, Richard (2005), Cities and the Creative Class, New York, NY, Routledge.

Folena, Gianfranco (1991), Volgarizzare e tradurre, Torino, Einaudi.

Follett, Mary Parker ([1927] 1941), "Leader and expert", in Dynamic Administration, The Collected Papers of Mary Parker Follett, New York, NY, Harper and Bros.

Frenkel, Michal (2005), "Something new, something old, something borrowed: the cross- national translation of the 'Family Friendly Organization' in Israel", in Barbara Czarniawska and Guje Sevón (eds), Global Ideas. How Ideas, Objects and Practices Travel in the Global Economy, Malmö / Copenhagen, Liber/CBS Press, 147-66.

Freud, Sigmund (1899), Die Traumdeutung, Leipzig und Wien, Franz Deuticke [tr. it 1976, a cura di C.L.E. Musatti, OSF (Opera Sigmund Freud), Torino, Bollati e Borlinghieri].

Gabriel, Yiannis (ed.) (2004), Myths, Stories, and Organizations. Premodern Narratives for Our Times, Oxford, Oxford University Press.

Gagliardi, Pasquale (ed.) (1990), Symbols and Artifacts: Views of the Corporate Landscape, Berlin, de Gruyter.

Gaggiotti, Hugo, Marre Diana (2017), “The words leader/líder and their resonances in an Italo-Latin American multinational corporation", Leadership, 13(2), 194-214.

Gergen, Kenneth J. (1994), Realities and Relationships. Soundings in Social Construction, Cambridge, MA, Harvard University Press.

Gherardi, Silvia (1998), Il genere e le organizzazioni, Milano, Raffaello Cortina Editore.

Giddens, Anthony (1991), Modernity and Self-identity: Self and Society in the Late Modern Age, Cambridge, Polity Press [tr. it., 1999, di M. Aliberti, A. Fattori, Identità e società moderna, Napoli, Ipermedium libri].

Giridharadas, Anand (2012), "Modern life intrudes on art of writing", International Herald Tribune, 2 February.

Goffman, Erving (1974), Frame Analysis. An essay on the organization of experience, Boston, MA, Northeastern University Press [tr. it. e a cura di 2001, di I. Matteucci, Frame analysis. L'organizzazione dell'esperienza, Roma, Armando Editore]. 
Graff, Agnieszka (2001), Świat bez kobiet [Il mondo senza le donne], Varsavia, WAB.

Graff, Agnieszka (2003), "Lost between the waves? The paradoxes of feminist chronology and activism in contemporary Poland", Journal of International Women's Studies, 4(2), 100-116.

Graff, Agnieszka (2008), "Why Poland is afraid of feminism", http:// www.bu.edu/articles/2008/why-poland-is-afraid-of-feminism/ (visitato 19 luglio 2020).

Grass, Günther (2002), Im Krebsgang, Göttingen, Steidl [tr. it. e a cura di 2004, di C. Groff, Il Passo del Gambero, Torino, Einaudi].

Greimas, Algirdas J. and Joseph Courtés (1979), Sémiotique: Dictionnaire raisonné de la théorie du langage, Paris, Classiques Hachette [tr. it. (1986; 2007), a cura di P. Fabbri, Semiotica: dizionario ragionato della teoria del linguaggio, Firenze, La casa Usher; Milano, Bruno Mondadori].

Grey, Christopher (2009), "Speed", in Philip Hancock and André Spicer (eds), Understanding Corporate Life, London, Sage, 27-45.

Grey, Christopher (2012), Decoding Organization. Bletchley Park, Codebreaking and Organization Studies, Cambridge, Cambridge University Press.

Hacking, Ian (1999), The Social Construction of What?, Cambridge, MA, Harvard University Press.

Håkansson, Hakan and Jan Johansson (eds) (2001), Business Networking Learning, Oxford, Pergamon Press.

Halpern, Sue (2012), "Are hackers heroes?", New York Review of Books, LIX.

Haraway, Donna (1991), Simians, Cyborgs and Women: The Reinvention of Nature, London, Free Association Books [tr. it. e a cura di 2018, di L. Borghi, Manifesto cyborg: Donne, tecnologie e biopolitiche del corpo, Milano, Feltrinelli].

Harré, Rom (ed.) (1986), The Social Construction of Emotions, Oxford, Blackwell [tr. it. 1992, di O. Pavirani Arcangeli, La costruzione sociale delle emozioni, Milano, Giuffrè].

Heldt, Barbara (1987), Terrible Perfection: Women and Russian Literature, Bloomington, IN, Indiana University Press.

Hellberg, Inga, Mike Saks and Cecilia Benoit (eds) (1999), Professional Identities in Transition: Cross- cultural Dimensions, Södertälje, Almqvist and Wiksell International. 
Hobsbawm, Eric (1983), "Introduction: inventing traditions", in Eric Hobsbawm and Terence Ranger (eds), The Invention of Tradition, Cambridge, Canto, 1-14 [tr. it. 2002, di E. Basaglia, "Introduzione: come si inventa una tradizione", in Eric Hobsbawm e Terence Ranger (a cura di), L'invenzione della tradizione, Torino, Einaudi, 3-18].

Holzner, Burkhart (1968), Reality Construction in Society, Cambridge, MA, Schenkman.

Jacobs, Jane (1961), The Death and Life of the Great American City, New York, NY, Random House.

Jacobsson, Bengt (1994), "On evil organizations and illusory reforms", in Barbara Czarniawska e Pierre Guillet de Monthoux (eds), Good Novels, Better Management. Reading Organizational Realities in Fiction, Reading, Harwood Academic Publishers, 65-92.

Joerges, Bernward and Barbara Czarniawska (1998), "The question of technology, or how organizations inscribe the world", Organization Studies, 19(3), 363-85.

Johnson, Richard (1986-87), "What is cultural studies anyway?", Social Text, 16(1986-7), 38-80.

Jordan, Tim (2007), "Technopower and its cyberfutures", in David Bell and Barbara M. Kennedy (eds), The Cybercultures Reader, London, Routledge, 594-601.

Kanter, Rosabeth Moss (1977), Men and Women of the Corporation, New York, NY, Basic Books.

Kartvedt, Sindre (1994-95), "Cyberpunk sage", Scanorama, December/ January, 54-8.

Katz, Daniel e Robert J. Kahn (1966), The Social Psychology of Organizations, New York, NY, John Wiley and Sons.

Knorr Cetina, Karin (1981), The Manufacture of Knowledge, Oxford, Pergamon.

Knorr Cetina, Karin (1994), "Primitive classification and postmodernity: towards a sociological notion of fiction", Theory, Culture and Society, 11(3), 1-22.

Korneliussen, Tor e Fabrizio Panozzo (2005), “From 'nature' to 'economy' and 'culture': how stockfish travels and constructs an action net", in Barbara Czarniawska e Guje Sevón (eds), Global Ideas. How Ideas, Objects and Practices Travel in the Global Economy, Malmö / Copenhagen, Liber/CBS Press, 106-25. 
Kunda, Gideon ([1992] 2006), Engineering Culture. Control and Commitment in a High- tech Corporation, Philadelphia, PA, Temple University Press [tr. it. 2000, di E. Recchia, L'ingegneria della cultura. Controllo, appartenenza e impegno in un'impresa ad alta tecnologia, Torino, Edizioni Comunità].

Kundera, Milan (1986), L'art du Roman, Paris, Gallimard [tr. it. 1988, di E. Marchi, L'arte del romanzo, Milano, Adelphi].

Kundera, Milan La lenteur (1995) Paris, Gallimard [tr. it. 1995, di E. Marchi, Lentezza, Milano, Adelphi].

Lamoreux, Naomi R. (2004), "Partnerships, corporations, and the limits on contractual freedom in U.S. History: an essay in economic, law and culture", in Kenneth Lipartito and David B. Sicilia (eds), Constructing Corporate America: History, Politics, Culture, New York, NY, Oxford University Press, 29-65.

Latour, Bruno (1986), “The powers of association”, in John Law (ed.), Power, Action and Belief, London, Routledge and Kegan Paul, 264-280.

Latour, Bruno (1993a), Aramis ou L'amour des techniques, Paris, la Découverte

Latour, Bruno (1993), We Have Never Been Modern, Cambridge, MA, Harvard University Press [tr. it. 2015, di G. Lagomarsino, C. Milani, Non siamo mai stati moderni, Elèuthera, Milano].

Latour, Bruno (1998), Artefaktens aterkomst, Stockholm, Nerenius and Santérus.

Latour, Bruno (1999), Pandora's Hope: An Essay on the Reality of Science Studies, Cambridge, MA, Harvard University Press.

Latour, Bruno (2005), Reassembling the Social. An Introduction to Actor Network Theory, Oxford, Oxford University Press.

Law, John (1994), Organizing Modernity, Oxford, Blackwell.

Leach, Edmund (1968), "Ritual", The International Encyclopedia of the Social Sciences, New York, NY, Free Press, 520-526.

Lépinay, Vincent Antonin (2011), Codes of Finance. Engineering Derivatives in a Global Bank, Princeton, NJ, Princeton University Press.

Lessig, Lawrence (1999), Code and Other Laws of Cyberspace, New York, NY, Basic Books.

Lewin, Kurt (1958), "Group decision and social change", in Eleanor Maccoby, Theodore Newcomb e Eugene L. Hartley (eds), Readings in Social Psychology, New York, NY, Holt, Rinehart and Winston. 
Lewis, Michael (1999), Liar's Poker, London, Hodder and Stoughton.

Lindahl, Marcus ([2005] 2020), "The little engine that could: on the 'managing' qualities of technology", in Barbara Czarniawska and Tor Hernes (eds), Actor- Network Theory and Organizing, Lund, Studentlitteratur, 45-65.

Lindblom, Charles (1979), "Still muddling, not yet through", Public Administration Review, 39(6), 517-26.

Löfström, Carina (2003), Hur Posten blev foretag. Om reformer och oversattning av ideer, Gothenburg, School of Business, Economics and Law at the University of Gothenburg.

Loft, Anne (1995), "Time is money", Studies in Cultures, Organizations and Societies, 1(1), 129-45.

Luhmann, Niklas (1984), Soziale Systeme. Grundriß einer allgemeinen Theorie [tr. it. 2001, di A. Febbraio e R. Schmidt, Sistemi sociali. Fondamenti di una teoria generale, Bologna, Il Mulino].

Luhmann, Niklas (1992), Beobachtungen der Moderne, Opladen, Westdeutscher Verlag [tr. it. 1995, di F. Pistola, Osservazioni sul moderno, Roma, Armando editore].

Maccoby, Michael (1981), The Leader: A New Face for American Management, New York, NY, Simon and Schuster.

MacIntyre, Alisdair (1981), After Virtue, London, Duckworth [tr. it. 2007, a cura di M. D'Avenia, Dopo la virtù: Saggio di teoria morale, Roma, Armando editore].

MacIntyre, Alisdair (1988), Whose Justice? Which Rationality? Three Rival Versions of Moral Enquiry, London, Duckworth [tr. it. 1995, di C. Calabi, Giustizia e razionalità. Milano, Anabasi].

March, James G. ([1971] 1988), “Technology of foolishness”, in Decisions and Organizations, Oxford, Blackwell, 253-65.

March, James G. (1994), A Primer on Decision Making, New York, The Free Press.

March, James G. and Johan P. Olsen (eds) (1976), Ambiguity and Choice in Organizations, Bergen, Norway, Scandinavian University Press.

Margalit, Avishai (2003), The Ethics of Memory, Cambridge, MA, Harvard University Press. [tr. it. 2007, di V. Ottonelli, L'etica della memoria, Bologna, Il Mulino].

Marjosola, Iiris and Albert Mills (eds) (2002), Gender, Identity and the Culture of Organizations, London, Routledge. 
Marrese, Michelle Lamarche (2002), A Woman's Kingdom. Noblewomen and the Control of Property in Russia, 1700-1861, Ithaca, NY, Cornell University Press.

Marton, Jan (2002), "Barneviks miljoner", GoteborgsPosten, 19 febbraio.

McLuhan, Marshall (1964), Understanding Media: The Extensions of Man, New York, NY, Signet Books [tr. it. 1967, Gli strumenti del communicare, Milano, Saggiatore].

Megens, Hellen and Martin, Brian (2003), “Cybermethod: An assessment", First Monday, 8(2), 3 February.

Melzer, Jonas (2011), "So fick robothandeln börserna att blixtkrascha", NyTeknik (7 October).

Michels, Robert ([1911] 1915), Zur Soziologie des Parteiwesens in der modernen Demokratie. Über die Untersuchungen oligarchischen Tendenzen des Gruppenlebens, Leipzig, Klinkhardt [tr. it. 1912, di A. Polledro, Sociologia del partito politico nella democrazia moderna: studi sulle tendenze oligarchiche degli aggregati politici, Torino, Unione Tipografico-Editrice Torinese].

Mintzberg, Henry (1973), The Nature of Managerial Work, New York, NY, Harper and Row.

Mintzberg, Henry (1999), "Managing quietly", Leader to Leader, 12(spring), 24-30.

Moberg, Åsa (2011), Vanninorna och jag [Le mie amiche ed io I], Stockholm, Natur and Kultur.

Monin, Nancy e John Monin (2003), "Re- navigating management theory: steering by the star of Mary Follett", in Barbara Czarniawska e Pasquale Gagliardi (eds), Narratives We Organize By, Amsterdam, John Benjamins, 57-74.

Orton, J. Douglas e Karl E. Weick (1990), “Loosely coupled systems: a reconceptualization", Academy of Management Review, 15(2), 203-23.

Pallas, Josef, Strannegård, Lars e Jonsson, Stefan (eds) (2014), Organizations and the Media, London, Routledge, 132-44.

Pompili Pagliari, Marcella (ed.) (2005), La sfida delle pari opportunita nel management delle risorse umane, Milano, Guerini e associati.

Panozzo, Fabrizio (2001), “Den överbefolkade ledningen", in Rolf Solli e Barbara Czarniawska (eds), Modernising av storstaden, Malmö, Liber, 74-83.

Parker, Martin (1998), “Judgment day: cyborganization, humanism and postmodern ethics", Organization, 5(4), 503-18. 
Perrow, Charles (1984), Normal Accidents, New York, NY, Basic Books.

Perrow, Charles (1986), Complex Organizations. A Critical Essay, New York, NY, McGraw- Hill.

Polanyi, Michael (1962), Personal Knowledge: Towards a Post- Critical Philosophy, London, Routledge and Kegan Paul, 2nd edition [tr it. e a cura di 1990, di E. Riverso, La conoscenza personale. Verso una filosofia post-critica, Milano, Rusconi].

Powell, Walter W. and Paul J. DiMaggio (eds) (1991), The New Institutionalism in Organizational Analysis, Chicago, IL, University of Chicago Press [tr. it. 2000, di L. Chiesara, Il neoistituzionalismo nell'analisi Organizzativa, Torino, Edizioni Comunità].

Power, Michael (1997), The Audit Society. Rituals of Verification, Oxford, Oxford University Press.

Propp, Vladimir, (1928), Morfologija skarzki, "Academia", Leningrad [tr. it. 1966, di G. Bravo, Morfologia della fiaba, con un intervento di C. Lévi Strauss e una replica dell'autore, Torino, Einaudi].

Raspe, Rudolf Erich (e altri) ([1785], 1971), The Adventures of Baron Münchhausen, New York, NY, Meridian [tr. it. 2006, di M. Merlini, (Raspe, Rudolf Erich, Gottfried A. Bürger) Le meravigliose avventure del barone di Münchhausen, Milano, Garzanti].

Read, Donald (1992), The Power of News: The History of Reuters, 1849 1989, Oxford, Oxford University Press.

Rice, Albert K. ([1958] 1987), Productivity and Social Organization: the Ahmedabad Experiment, London, Tavistock.

Robertson, Roland (1992), Globalization. Social Theory and Global Culture, London, Sage.

Robertson, Roland (1995), "Glocalization: time- space and homogeneityheterogeneity", in Mike Featherstone, Scott Lash e Roland Robertson (eds), Global Modernities, London, Sage, 25-44.

Rogers, Everett (1962), Diffusion of Innovation, New York, NY, Free Press. Rombach, Björn e Rolf Solli (2006), Constructing Leadership. Reflections on Film Heroes as Leaders, Stockholm, Santérus Academic Press.

Rorty, Richard (1982), Consequences of Pragmatism, Minneapolis, MN, University of Minnesota Press [tr. it. 1986, di F. Elefante, Conseguenze del pragmatismo, Milano, Feltrinelli].

Sahlin- Andersson, Kerstin (1996), "Imitating by editing success: the construction of organizational fields", in Barbara Czarniawska 
e Guje Sevón (eds), Translating Organizational Change, Berlin, de Gruyter, 69-92.

Sapir, Edward (1921), Language: An Introduction to the Study of Speech, New York, NY, Harcourt Brace and Co [tr. it. e a cura di 1969, P. Valesio, Il linguaggio. Introduzione alla linguistica, Torino, Einaudi]. Sapir, Edward (1931), "Fashion", Encyclopedia of the Social Sciences, New York, NY, Macmillan, 139-44.

Sassen, Saskia (2001), The Global City. New York, London, Tokyo, Princeton, NJ, Princeton University Press.

Scarry, Elaine (1985), The Body in Pain: The Making and Unmaking of the World, New York, NY, Oxford University Press.

Schütz, Alfred (1962), "Common sense and scientific interpretation of human action", in Collected Papers, Vol. I: The problem of social reality, The Hague: Martinus Nijhoff, 3-47 [tr. it. 1979, di A. Izzo, "L'interpretazione dell'azione umana da parte del senso comune e della scienza", in Saggi sociologici, Torino, Utet].

Schwartz, Birgitta (2006), "Environmental strategies as automorphic patterns of behaviour", Business Strategy and the Environment, 18(3), 192-206.

Selznick, Philip ([1949] 1966), TVA and the Grass Roots, New York, Harper and Row.

Sevón, Guje (2003), “Performing Northern Lights! Contemporary research on management and organization", keynote address at the 17th Nordic Conference on Business Studies, Reykjavik, Iceland, 14-16 August.

Sevón, Guje and Kristian Kreiner (eds) (1998), Constructing RED Collaboration, Copenhagen, CBS Press.

Shenhav, Yehouda (1999), Manufacturing Rationality: The Engineering Foundations of the Managerial Revolution, Oxford, Oxford University Press.

Shirky, Clay (2008), Here Comes Everybody: The Power of Organizing Without Organizations, London, Allen Lane.

Shrivastava, Paul (1993), "Crisis theory/practice: towards sustainable development", Industrial and Environmental Crisis Quarterly, 7(1), 23-42.

Silverman, David and Brian Torode (1980), The Material Word. Some Theories of Language and its Limits, London, Routledge and Kegan Paul. 
Simmel, Georg (1923), Soziologie. Untersuchungen rdie Formen der Vergesellschaftung, Münchhausen-Leipzig, Duncker-Humblot [tr. it. 1993, di A. M. Meta Galioto, in E. Pozzi (a cura di), Lo straniero interno, Firenze, Ponte alle Grazie, 25-29].

Simmel, Georg ([1895 “Die Mode”]; 1904), “Fashion”, International Quarterly, 10(1), 130-155 [tr. it. 1885, di M. Monaldi, La moda e altri saggi di cultura filosofica, Milano, Longanesi].

Sismondo, Sergio (1993), "Some social constructions", Social Studies of Science, 23, 515-53.

Smircich, Linda e Gareth Morgan (1982), "Leadership: the management of meaning", The Journal of Applied Behavioral Science, 18(3), 257-73.

Smith, Dorothy E. (1987), The Everyday World as Problematic. A Feminist Sociology, Milton Keynes, Open University Press.

Smith Ring, Peter eAndrew H. Van De Ven (1992), "Structuring cooperative relationships between organizations", Strategic Management Journal, 13(7), 483-98.

Sokołowska, Magdalena (1981), “Women in decision- making elites: the case of Poland", in Cynthia Fuchs Epstein e Rose Laub Coser (eds), Access to Power: Cross- national Studies of Women and Elites, London, Allen and Unwin, 90-114.

Solli, Rolf e Barbara Czarniawska (2001), “Vad är pa modet i storstaden?”, in Rolf Solli , Barbara Czarniawska (eds), Modernisering av storstaden: Marknad och management $i$ stora stader vid sekelskifte, Malmö, Liber, 5-14.

Stogdill, Ralph Melvin (1948), "Personal factors associated with leadership: A survey of literature", Journal of Psychology, 25(1948), 35-71.

Strannegård, Lars e Maria Friberg (2001), Already Elsewhere, Stockholm, Raster Förlag.

Strawson, Galen (2000), "Against narrativity", Ratio (new series), XVII, 4 December.

Strindberg, August (1879), The Red Room, New York, NY, G.B. Putnam's Sons [tr. it. 1993. La stanza rossa, Roma, Newton \& Compton Editori]. Tarde, Gabriel ([1890] 1895), Les lois de l'imitation: étude sociologique, Paris, F. Alcan Ėditeur [tr. it. e a cura 2012, di Filippo Domenicali, Le leggi dell'imitazione, Torino, Rosenberg \& Sellier].

Tengblad, Stefan (ed.) (2013), The Work of Managers. Towards a Practice Theory of Management. Oxford, Oxford University Press. 
Todorov, Tzvetan (1998), Le Jardin imparfait : La pensée humaniste en France, Paris, Éditions Grassett.

Tuchman, Gaye (1978), Making News. A Study in the Construction of Reality, New York, Free Press.

Tullberg, Maria (2000), Växelsång. Om organisering för förändring på SJ, Gothenburg, BAS.

Turner, Barry A. ([1978] 1996), Manmade Disasters, London, Wykeham Press [tr. it. 2001, di M. Merzagora, Barry A. Turner, Nick F. Pidgeon, Disastri: la responsabilità dell'uomo nelle catastrofi, Roma, Edizioni Comunità].

Turner, Victor (1982), From Ritual to Theatre. The Human Seriousness of Play, New York, NY, Performing Arts Journal Publications [tr. it. 2013, di P. Capriolo, a cura di S. De Matteis, Dal rito al teatro, Bologna, Il Mulino].

Varese, Federico (2004), "Great mobility", Times Literary Supplement, 2 July, 6.

Vaughan, Diana (1999), “The dark side of organizations: mistake, misconduct and disaster", Annual Review of Sociology, 25(1999), 271305.

Vedung, Evert (2000), Public Policy and Program Evaluation, New Brunswick, NJ, Transaction Publishers.

Walczewska, Sławomira (2000), Damy, rycerze i feministki. Kraków, eFKa.

Warren, Roland L., Stephen M. Rose and Ann F. Bergunder (1974), The Structure of Urban Reform: Community Decision Organizations in Stability and Change, Lexington, MA, D.C. Heath.

Weick, Karl ([1969] 1979), The Social Psychology of Organizing, Reading, MA, Addison- Wesley [tr. it. 1993, di L. Casotto, a cura di B, Bernardi e M. Warglien, La psicologia sociale dei processi organizzativi, Milano, Isedi].

Weick, Karl E. (1976), “Educational organizations as loosely coupled systems", Administrative Science Quarterly, 21(1), 1-19.

Weick, Karl E. (1988), "Enacted sensemaking in crisis situations", Journal of Management Studies, 25(4), 305-17.

Weick, Karl E. (1995), Sensemaking in Organizations, Thousand Oaks, CA, Sage [tr. it. 1997, di L. Formentini, Senso e significato nell'organizzazione, Milano, Raffaello Cortina Editore].

Weick, Karl E. (1996), “Drop your tools: an allegory for organization studies", Administrative Science Quarterly, 41(2), 301-13. 
Weick, Karl E. and Robert E. Quinn (1999), “Organizational change and development", Annual Review of Psychology, 50(1999), 361-86.

Weick, Karl E. and Kathleen M. Sutcliffe (2001), Managing the Unexpected, San Francisco, CA, Jossey- Bass.

White, Hayden (1973), Metahistory. The Historical Imagination in NineteenthCentury Europe, Baltimore, MD, Johns Hopkins University Press [tr. it. (1978), Retorica e storia, Napoli, Guida editore; (2019), a cura di P. Vitulano, Metahistory retorica e storia, Milano, Meltemi].

White, Hayden (1987), The Content of the Form. Narrative Discourse and Historical Representation. Baltimore, MD, Johns Hopkins University Press [tr. it. a cura di 2006, di E. Tortarolo, Forme di storia: dalla realtà alla narrazione, Roma, Carocci].

Whorf, Benjamin L. (1936), "A linguistic consideration of thinking in primitive communities", in John B. Carroll (ed.), Language, Thought and Reality. Selected Writings of Benjamin Lee Whorf, Cambridge, MA, MIT Press, 112-24 [tr. it. 1995, di F. Ciafaloni, a cura di J.B. Carroll, "Analisi linguistica del pensiero nelle comunità primitive", in Linguaggio, pensiero e realtà, Torino, Bollati Borlinghieri, 50-71].

Williams, Rosalind (1990), Notes on the Underground. An Essay on Technology, Society, and the Imagination, Cambridge, MA, MIT Press.

Winnicka, Ewa (2011) "Polskie feministki od 1989 do dziś", https:// www.polityka.pl/tygodnikpolityka/spoleczenstwo/1519544,1,polskie-feministki-od-1989-do-dzis.read (visitato 19 luglio 2020).

Winroth, Karin (2002), The Organizing of Expert Firms, Gothenburg, GRI Report 2002, 4.

Woodward, Joan (1965), Industrial Organization. Theory and Practice, Oxford, Oxford University Press [tr. it. 1983, di S. Scamuzzi, Organizzazione industriale. Teoria e pratica, Torino, Rosenberg \& Sellier].

Young, Agnes Brooks ([1937] 1973), "Recurring cycles of fashion", in Gordon Wills and David Midgley (eds), Fashion Marketing, London, Allen and Unwin, 107-24.

Yukl, Gary (1971), “Toward a behavioral theory of leadership”, Organizational Behavior and Human Performance, 6(4), 414-40.

Yukl, Gary ([2001] 2012), Leadership in Organizations, New York, NY, Prentice- Hall, $8^{\circ}$ ed. 


\section{Indice dei nomi}

Abbott, Andrew, 88; 259

Adolfsson, Petra, 78; 259

Acker, Joan, 199; 200; 205; 259

Ahrne, Göran, 230; 259

Ancori, Bernard, 114; 259

Alessandro II (Romanov, zar), 126

Allport, Flyd H., 44; 154-5

Alvesson, Mats, 141; 143; 145; 150; 212

Arnold, Thurman Wesley, 114; 259

Aronson, Elliot, 24; 259

Austin, John L., 114; 259

Bacharach, S., 253n.; 264

Badham, Richard, 160n.; 259

Bailyn, Lotte L., 200-1; 259

Barnevik, Percy, 133; 145; 271

Baudouin de Courtenay Ehrenkreutz Jędrzejewicz, Cezaria, 200

Bauman, Zygmunt, 22; 25; 228; 260

Beda (il Venerabile), 68

Becker, Howard S., 160n.; 260

Benoit, Cecilia, 135; 267

Benschop, Yvonne, 199; 260

Berger, Peter, 21; 27; 51; 240; 260

Bergunder, Ann F., 156; 260

Billig, Michael, 42; 260

Blumer, Herbert G., 188; 191; 260

Bonazzi, Giuseppe, 3; 8; 18; 33n.;

41n.; 239; 260
Boncori, Ilaria, 89

Borges, Jorges L., 117; 260

Bourdieu, Pierre, 35-6; 47; 195-8;

196n. 205; 210; 260

Bowker, Geoffrey C., 125; 130;

260-1

Brett, Simon, 139; 261

Brose, Hans-Georg, 225-6; 228; 261

Brežnev, Leonid Ilic, 98

Brouns, Margo, 199; 260

Bruner, Jerome, 12; 65; 261

Brunsson, Nils, 75; 76n.; 125; 135;

150; 155; 164; 167; 174; 194; 230;

250; 259; 261

Bürger, Gottfried A., 174; 272

Burns, Tom 92; 261

Butera, Federico, 3; 8; 18; 247;

252n.

Calás, Marta, 200-1

Callon, Michel, 131; 261

Candea, Matei, 185n.; 261

Camus, Albert, 146; 149

Carlo (Carlo Martello, re di Fran-

cia) 68-9

Carlson, Sune, 135; 261

Case, Peter, 213; 226n; 261

Chaboud, Alain, 223; 261

Cleese, John, 139 
Clegg, Stewart, 38; 209-11; 261-2

Clements, Samuel C., 126

Cohendet, Patrick, 114; 259; 262

Colwill, Nina, 199

Connerton, Paul, 159; 262

Corvellec, Hervé, 53; 192

Cowan, Robin, 114; 262

Cowan, Robin, 114; 262

Cowan, Ruth S., 262

Crozier, Michel, 240n.

Darnton, Robert, 53, 265

Davies, Norman, 231; 265

Devoto, Giacomo,114n.; 265

Diamond, Jared, 109; 265

DePamphilis, Donald, 231, 265

Diedrich, Andreas, 162-4; 265

DiMaggio, Paul J., 46-47; 179

Dobers, Peter, 192; 265

Eco, Umberto; 177n.; 265

Edipo, 149

Eriksen, Thomas H., 218; 265

Eriksson, Ulla, 142; 265

Erlingsdottir, Gudbjörg, 49; 181; 265

Feldman, Martha S., 39n.; 265

Ferraris, Maurizio, 16

Ferrarotti, Franco, 240n.

Fiedler, Fred E., 134; 266

Florida, Richard, 53; 256

Folena, Gianfranco, 177n.; 266

Follett, Mary P., 140-1; 144; 151;

244; 250; 266; 271

Frenkel, Michal, 203-4; 210

Freud, Sigmund, 77; 149; 266

Gabo, Naum, 22

Gabriel, Yiannis, 149; 266

Gagliardi, Pasquale, 93; 151; 153n.; $264 ; 266 ; 271$
Gaggiotti, Hugo, 39n-40n.; 266

Gallino, Luciano, 240n.

Gecko, 148

Geertz, Clifford J., 19

Genell, Kristina, 263

Gergen, Kenneth, 23; 266

Gerstner, Louis, 144-5

Gherardi, Silvia, 212; 266

Gibson, William, 147

Giddens, Anthony, 176; 266

Giridharadas, Anand, 213; 266

Goffman, Erving, 243; 266

Gombrowicz, Witold, 207

Gottfried, duca degli Alemanni (650-709), 68

Graff, Agnieszka, 110; 205-6; 2089; 267

Granovetter, Mark, 249

Grass, Günter, 231; 267

Greimas Algirdas J., 16; 51n.; 267

Grey, Christopher, 116n.; 123; 132;

225-6; 267

Gyllenhammar, Pehr, 134

Friberg, Maria, 138; 149; 151, 274

Fuchs Epstein, Cynthia, 274

Hacking, Ian, 26; 267

Håkansson, Hakan, 231; 267

Halpern, Sue, 115; 117; 267

Hanchard, Michael, 197

Haraway, Donna, 92; 267

Harré, Rom, 23; 267

Heinlein, Robert A., 170

Heldt, Barbara, 195; 267

Hellberg, Inga, 135; 267

Hirschman, Albert, 252

Hobsbawm, Eric J. E., 268

Holzner, Burkhart, 21-2; 268 
Jacobs, Jane, 189; 268

Jacobsson, Bengt, 75; 125; 194; 229;

$261 ; 263 ; 268$

Joerges, Bernward, 92; 109; 144;

153n.; 159; 169; 176-8; 263-4; 265; 268

Johansson, Jan, 231; 267

Johnson, Richard, 148; 268

Jordan, Tim, 131; 268

Kahn, Robert L., 154; 268

Kanter, Rosabeth M., 52; 268

Kartvedt, 147; 268

Katz, Daniel, 154; 268

Kern, Horst, 240n.

Kieślowski, Krzysztof, 105

Knorr Cetina, Karin, 23; 38; 91; $165 ; 268$

Konopnicka, Maria, 207

Korneliussen, Tor, 227; 268

Kunda, Gideon, 44; 269

Kundera, Milan, 227-8; 269

Lamoreux, Naomi R., 233; 269

Latour, Bruno, 22-3; 29; 91; 94; 108;

111; 168-9; 183; 193; 233; 235; 249;

269

Laub Coser, Rose, 274

Law, John, 41; 269

Leach, Edmund, 181; 269

Lépinay, Vincent A., 118-20; 269

Lessig, Lawrence, 109; 113; 269

Lewin, Kurt, 47; 158; 269

Lilley, Simon, 213; 226n.; 261

Lindahl, Marcus, 170-1; 270

Lindberg, 181; 265

Lindblom, Charles, 145; 270

Lipartito, Kenneth, 269

Lissitzky, El, 22
Löfström, Carina, 164-5; 167; 270

Luckmann, Thomas, 21; 27; 51; 260

Luhmann, Niklas, 155-6; 159;

167n.; 191; 240n.; 270.

Maccoby, Michael, 148; 269-70

MacIntyre, Alisdair, 12; 14; 147;

270

March, James G., 135; 173-4; 270

Margalit, Avishai, 149; 270

Marjosola, Iiris, 212; 270

Marre, Diana, 39n-40n.; 266

Marrese, Michelle L., 195; 271

Martin, Brian, 230; 271

Marton, Jan, 133-5; 138; 271

Maturana, Humberto, 155

Mazza, Carmelo, 31n.; 159; 159;

186; 264-5

McLuhan, Marshall, 225; 271

Megens, Hellen, 230; 271

Melzer, Jonas, 223; 271

Merton, Robert K., 240

Merzagora, M., 111; 275

Michels, Robert, 231; 271

Mintzberg, Henry, 135; 144-6; 150-

$1 ; 261 ; 271$

Miller, James G., 154

Mills, Albert, 212; 270

Moberg, Åsa, 194-5; 271

Moholy-Nagy, László, 22

Molière (Poquelin, Jean-Baptiste), 235

Monin, John, 151; 271

Monin, Nancy, 151; 271

Morgan, Gareth, 141; 274

Münchhausen, Karl Friedrich Hieronymus von, Barone di, 13; 170;

173-5; 153-4; 250; 272 
Mundell, Brian, 153n., 264

Nałkowska, Zofia, 207

Oli, Gian Carlo, 114n., 265

Olsens, Johan P., 77; 155; 174; 203; 261; 270

Orton, J. Douglas, 77; 271

Orzeszkowa, Eliza, 207

Owen, Tom, 213; 226n.; 261

Panozzo, Fabrizio, 182; 227; 268; 271

Parker, Martin, 235; 251; 271

Parsons, Talcott, 150; 240

Perrow, Charles, 93; 232; 272

Peters, Tom, 43

Petrini, Carlo, 226

Pevsner, Antoine, 22

Piaget, Jean, 23; 198

Pidgeon, Nick F., 111

Pipan, Tatiana, 31n.; 186; 255

Pipino (di Herstal, 640-714), 68-9

Piro, Francesco, 5; 9-19; 89; 263

Pizzorno, Alessandro, 240n.

Podoski, Jan, 108

Poggio, Barbara, 3; 8; 253

Polanyi, Michael, 114; 272

Powell, Walter W., 46-7; 179; 249; 272

Power, Michael, 59; 63; 272-3

Propp, Vladimir, 65; 272

Putnam, Hilary, 14

Puzo, Mario, 147

Quinn, Robert E., 158; 173; 276

Ranger, Terence, 268

Ramsete II, faraone, 22

Raspe, Rudolf E., 153-4; 174; 272

Rhodes, Carl, 264

Ricoeur, Paul, 14
Rice, Albert K., 92; 272

Richerio di Reims, 70

Robertson, Roland, 179-80; 196;

272

Rogers, Everett, 168; 172

Rombach, Björn, 148; 272

Rorty, Richard, 14; 77; 272

Sahlin-Andersson, Kerstin, 80n.;

272

Saks, Mike, 135; 267

Samozwaniec, Magdalena, 207

Sapir, Edward, 41; 185; 273

Sassen, Saskia, 271

Scarry, Elaine, 233; 273

Schapiro, Mary, 222-223

Schumann, Michael, 20n.

Schütz, Alfred, 21-2; 194; 273

Schwartz, Birgitta, 134; 273

Selznick, Philip, 46-7; 240; 273

Senge, Peter, 9

Sevón, Guje, 139; 169; 192; 195;

198; 200; 233; 259; 263-6; 268; 273

Shenhav, Yehouda, 78; 273

Shirky, Clay, 229; 273

Shrivastava, Paul, 93; 273

Sicca, Luigi M., 3-4; 9-19; 11n.;

13n.; 17n.; 89; 248n.; 263-4

Sicilia, David B. 269

Silverman, David, 76; 273

Simmel, Georg, 188; 200-1; 274

Simon, Hebert, 240

Sisifo, 149

Sismondo, Sergio, 24; 274

Slavova, Kornelia, 205

Smircich, Linda, 141; 274

Smith, Dorothy, 194; 274

Smith Ring, Peter, 231; 274 
Sokołowska, Magdalena, 206-8; 274 Turner, Barry, A., 93; 111, 275

Solli, Rolf, 53; 148; 167; 262; 264; Turner, Victor, 160

271-2; 274

Van De Ven, Andrew H., 231; 274

Sperber, Dan 15

Stalker, G.M., 92; 261

Varela, Francisco J., 155

Varese, Federico, 147; 275

Star, Susan L., 125; 261

Vaughan, Diana, 93; 275

Steinmueller, Edward, 114; 262

Stewart, Rosemary, 261

Vedung, Evert, 161; 275

von Trier, Lars, 139

Stogdill, Ralph M., 132n.; 274

Walczewska, Sławomira, 209; 275

Strannegård, Lars, 113n.; 138; 149;

Warren, Roland L., 156; 275

$151 ; 265 ; 271 ; 274$

Wacquant, Loic 195-8; 196n. 205;

Strawson, Galen, 65; 274

210; 260

Strindberg, August, 229-30; 274

Waterman, Robert, 43

Tarde, Gabriel, 15; 53; 168; 184-6;

191-2;

Weick, Karl E., 42; 67; 67n.; 74; 77;

$141 ; 174 ; 275$

Tatlin, Vladimir, 22

Westwood, Robert, 38; 262

Tengblad, Stefan, 140; 274

White, Hayden, 12; 14; 68; 70; 276

Theudo, di Aquitania, 68

Whorf, Benjamin, 41; 276

Thompson, James D., 20n.

Williams, G.P., 126

Todorov, Tzvetan, 24; 275

Williams, Rosalind, 96; 105; 276

Torode, Brian, 76; 273

Winnicka, Rosalid, 209; 276

Touraine, Alain, $240 \mathrm{n}$.

Winroth, Karin, 136; 276

Tuchman, Gaye, 125; 275

Woodward, Joan, 92; 240n., 276

Tullberg, Maria, 166; 275

Yukl, Gary, 134, 276

Turing, Alan, 117

Zapolska, Gabriela, 207 



\section{Hanno scritto nella Collana punto org}

www.puntoorg.net

1. L.M. Sicca (a cura di)', Leggere e scrivere organizzazioni. Estetica, umanesimo e conoscenze manageriali (con postfazione di F. Piro), 2010.

2. L.M. Sicca, Alla fonte dei saperi manageriali. Il ruolo della musica nella ricerca per l'innovazione e per la formazione delle risorse umane, 2012.

3. A. Di Scipio, Pensare le tecnologie del suono e della musica (con prefazione di R. Diana), 2012.

4. R. Musto, Scienza Natura Cambiamento (con prefazione di M. Nicodemi), 2012.

5. R. Musto, Novalis. L'assoluto e le cose (con prefazione di C. Albarella e postfazione di G. Imbruglia), 2013.

6. Aa.Vv. II I linguaggi dell'organizzare. Musica e testo tra dono e disinteresse, 2013.

7. B. Masiello, Fiducia nelle reti. Strategie per la crescita nei mercati internazionali delle PMI (con prefazione di F. Izzo), 2013.

8. Aa.Vv. II, Tavola rotonda. Umanesimo del management attraverso gli occhi dell'altro, 2013.

9. M. Calcagno, Narrare terre di mezzo. Management arte design (con prefazione di S. Faccipieri e postfazione di A. Comacchio), 2013.

10. R. Diana, Disappartenenza dell'To. Filosofia e musica verso Samuel Beckett (con prefazione di L.M. Sicca), 2014.

${ }^{1}$ Con scritti di Per Olof Berg e Kristian Kreiner, Robert W. Witkin, Barbara Czarniawska e Carl Rhodes, Ken Starkey e Sue Tempest, John Hendry, Karin Knorr Cetina.

" Con scritti di Luigi Maria Sicca, Umberto di Porzio, Rosario Diana, Agostino Di Scipio, Mariella De Simone, Bernardo Maria Sannino, Chiara Mallozzi, Lorenzo Pone, Giancarlo Turaccio.

"I Con scritti di Luigi Maria Sicca, Francesco Izzo, Maura Striano, Giulia Dell'Aquila, Felice Casucci, Francesco Perillo, Rosario Diana, Paola Giampaolo, Davide Bizjak, Gilberto-Antonio Marselli, Franco Vitelli, Maria Rosaria Napolitano. 
11. Aa.Vv. ${ }^{\text {Iv }}$, Sergio Piro. Maestri e allievi, 2014.

12. F.D. Perillo (a cura di) ${ }^{\mathrm{v}}$, Impresa imperfetta, 2014.

13. L.M. Sicca, L. Zan (a cura di) ${ }^{\mathrm{vi}}$, Management Arti Culture. Resoconto del primo anno del GSA - Accademia Italiana di Economia Aziendale, 2014.

14. M. Iaccarino, Un mondo assetato. Come il bisogno di acqua plasma la civiltà (con prefazione di F.P. Casavola e postfazione di A. Giannola), 2015.

15. F. Piro, Manuale di educazione al pensiero critico. Comprendere e argomentare (con prefazione di T. De Mauro), 2015.

16. F. D'Errico, Fuor di metafora. Sette osservazioni sull'improvvisazione musicale (con prefazione di P. de Vita e postfazione di M. Maldonato), 2015.

17. E. Mollona, Computer Simulation in Social Sciences. A Logic of Enquiry (with a preface by L.M. Sicca, a foreword by G. Colombo and an afterword by D. Secchi), 2015.

18. S. Oliverio, L.M. Sicca, P. Valerio ${ }^{\mathrm{vI}}$, Transformare le pratiche nelle organizzazioni di lavoro e di pensiero (con prefazione di G. Manfredi), 2015.

19. P. Valerio, C. Bertolazzi, P. Marcasciano (a cura di) ${ }^{\mathrm{v} m}$, Transformare l'organizzazione dei luoghi di detenzione. Persone transgender e gender nonconforming tra diritti e identità (con prefazione di L.M. Sicca), 2016.

iv Con scritti di Giuseppe Cantillo, Tullio De Mauro, Aldo Masullo, Mariapaola Fimiani, Teresa Capacchione, Antonio Mancini, Roberto Beneduce, Enrico De Notaris, Fulvio Marone, Dario Stefano Dell'aquila, Luigi Maria Sicca, Francesco Piro.

v Con scritti di Pier Luigi Celli, Eugenio Mazzarella, Enzo Rullani, Luigi Maria Sicca, Francesco Varanini.

vi Con scritti di Stefano Baia Curioni, Paola Dubinie Ludovica Leone, Sara Bonini Baraldi e Luca Zan, Monica Calcagno e Luigi M. Sicca, Donata Collodi, Francesco Crisci e Andrea Moretti, Roberto Ferrari e Alessandro Hinna, Francesco Giaccari, Francesca Imperiale e Valentina Terlizzi, Daniele Goldoni, Pamela Palmi.

vi Con scritti di Anna Lisa Amodeo, Christian Ballarin, Davide Bizjak, Ilaria Boncori e Paolo Fazzari, Rossella Bonito Oliva, Simone Cangelosi, Marco De Giorgi, Guglielmo Faldetta, Vittoria Fiorelli, Stefano Maltese, Porpora Marcasciano, Piergiorgio Masi, Antonia Monopoli e Chiara Repetto, Andrea Morniroli, Edoardo Mollona, Cristiano Scandurra, Luca Solari, Maria Spanò, Maria Gigliola Toniollo.

viI Con scritti di: Paolo Valerio, Giuseppe Ferraro, Carmen Bertolazzi, Alexander Hochdorn, Porpora Marcasciano, Luca Chianura, Damiana Massara, Daniela A. Nadalin, Adriana Godano, Luca Chianura, Vittoria Colonna, Elia De Caro, Tito Flagella, Anna Lorenzetti. 
20. M.R. Napolitano, V. Marino (a cura di) ${ }^{\mathrm{Ix}}$, Cultural Heritage e Made In Italy. Casi ed esperienze di marketing internazionale (con prefazione di G. Volpe e postfazione di A. Mattiacci), 2016.

21. M. Lusiani, Discourses of Planning (with a preface by L. Zan and an afterword by A. Langley), 2016.

22. F.D. Perillo, Simposio manageriale (con prefazione di A. Masullo e postfazione di P.L. Celli), 2016.

23. P. Ferri, I commissariamenti nel settore culturale italiano. Obiettivi, azioni, risultati (con prefazione di L. Zan e postfazione di G. Grossi), 2016.

24. L. Pareschi, Controcampo letterario. Strategie di intermediazione e accesso all'industria editoriale (con prefazione di P. Dubini e postfazione di G. Colombo), 2016.

25. G.-A. Marselli, Mondo contadino e azione meridionalista. L'esperienza del Gruppo Rossi-Doria a Portici (con prefazione di E. Mazzetti e postfazione di F. Vitelli), 2016.

26. F. Accardix, Risk and Control Governance. A value-creation perspective (with a preface by A. De Nicola; an introduction by V. Atella and an afterword by S. Bozzolan), 2017.

27. I. Boncori (ed.) $)^{x_{1}}, L G B T+$ Perspectives. The University of Essex Reader, (with a foreword by A. Forster), 2017.

28. A. Papa, "... Una cappella cavata dentro il monte...". Storia minima del complesso monastico di S. Lucia al Monte (con prefazione di L. d'Alessandro), 2017.

זx Con scritti di Loretta Battaglia, Giuseppe Bertoli, Roberta Biandolino, Michelle Bonera, Enrico Bonetti, Mauro Cavallone, Elena Cedrola, Marta Cerquetti, Maria Chiarvesio, Anna Codini, Emanuela Conti, Eleonora Di Maria, Barbara Francioni, Antonella Garofano, Francesco Izzo, Giulia Lanzilli, Gaetano Macario, Giulio Maggiore, Francesca Magno, Vittoria Marino, Barbara Masiello, Michela Matarazzo, Alberto Mattiacci, Marta Maria Montella, Fabio Musso, Maria Rosaria Napolitano, Alessandro Pagano, Tonino Pencarelli, Giovanna Pegan, Michele Quintano, Riccardo Resciniti, Marcello Risitano, Angelo Riviezzo, Savino Santovito, Elisabetta Savelli, Michele Simoni, Annarita Sorrentino, Raffaella Tabacco, Donata Vianelli.

${ }^{x}$ Con scritti di Roberto Rosato, Nicoletta Mincato, Carlo Nicoletti, Paolo De Paolis, Alessandro Salibra Bove.

${ }^{x}$ Con scritti di Alison J. Taylor-Lamb, Jamie Raines, Thomas Currid and Carl Chandra, Martin Harrison and Peter Martin, Rainer Shulze, Fleur Jeans and Teresa Eade, Tuesday Wats, Amy Anderson, Sco Lawley. 
29. R. Diana, L.M. Sicca, G. Turaccio ${ }^{\mathrm{xI}}$, Risonanze. Organizzazione, musica, scienze (con prefazione di A. Strati e postfazione di A. Solbiati), 2017.

30. F. D'Errico, Armonia funzionale e modalità. Rudimenti per l'improvvisazione a indirizzo jazzistico (con introduzione di F. Piro e prefazione di R. Grisley), 2017.

31. M. Calcagno, Interpreting Innovation. Design Creativity Art (with a foreword by F. Izzo; preface by A. Moretti and an afterword by J. Metelmann), 2017.

32. G. Balirano, Gardai \& Badfellas: The Discursive Construction of Organised Crime in the Irish Media (with a foreword by L.M. Sicca), 2017.

33. M.C. Mason, A. Moretti, Tattoo Management. Mercati, attori, valore, 2017.

34. P. Testa, Innovazione del modello di business. Le dimensioni latenti nella letteratura di management (con prefazione di L. Cantone), 2017.

35. L. Massa, Viva 'o re! Municipio e dintorni (con introduzione di L.M. Sicca; prefazione di E. Borgonovi e postfazione di C. Mochi Sismondi), 2017.

36. F. Pavan, Memini. Piccole storie di storia della musica (con introduzione di E. Mazzarella; prefazione di R. Alessandrini e postfazione di V. Moroni), 2017.

37. C. Mallozzi, D. Tortora ${ }^{\mathrm{x}}$, La bottega del suono. Mario Bertoncini. Maestri e allievi (con prefazione di M. Nicodemi e postfazione di L.M. Sicca), 2017.

38. G. Melis, Collaborazione e apprendimento nei processi di co-creazione di valore. Il caso delle destinazioni turistiche (con prefazione di M.R. Napolitano e postfazione di B. Argiolas), 2018.

39. G. Viglia, A.C. Invernizzi, Il ruolo dell'hubris nella gestione imprenditoriale (con prefazione di C. Mauri), 2018.

xII Con scritti di Davide Bizjak, Dario Casillo, Rosario Diana, Umberto Di Porzio, Agostino Di Scipio, Chiara Mallozzi, Mario Nicodemi, Lorenzo Pone, Rosalba Quindici, Sonia Ritondale, Tommaso Rossi, Bernardo Maria Sannino, Luigi Maria Sicca, Cristian Sommaiuolo, Giancarlo Turaccio, Paolo Valerio.

xIII Con scritti di Mario Bertoncini, Davide Bizjak, Gianmario Borio, Pietro Cavallotti, Andrew Culver, Francesco D'Errico, Charles de Mestral, Michelangelo Lupone, Chiara Mallozzi, Alessandro Mastropietro, Mario Nicodemi, Luigino Pizzaleo, Lorenzo Pone, Ingrid Pustijanac, John Rea, Bernardo Maria Sannino, Luigi Maria Sicca, Daniela Tortora. 
40. T. Russo Spena, C. Mele, Practising innovation. A Sociomaterial View (with a foreword by E. Gummesson; preface by J. Spohrer and an afterword by P. Stampacchia), 2018.

41. I. Boncori, Race, Ethnicity and Inclusion. The University of Essex Reader (with a foreword by A. Forster and a postface by M. Śliwa), 2018.

42. K.E. Russo, The Evaluation of Risk in Institutional and Newspaper Discourse. The Case of Climate Change and Migration (with a preface by G. Bettini), 2018.

43. R. Pera, When Consumers get Creative. Cocreation in the Individual and Collective Realm (with a preface by D. Dalli), 2018.

44. F. Piro, L.M. Sicca, P. Maturi, M. Squillante, M. Striano (a cura di) ${ }^{\mathrm{xIV}}$, Sfide didattiche. Il pensiero critico nella scuola e nell'università (con prefazione di F. Sabatini), 2018.

45. R. Quaglia, Bravi ma basta! Su certe premesse, promesse e catastrofi culturali (con introduzione di L.M. Sicca; prefazione di J. Mills e postfazione di F. Barca), 2018.

46. B. Czarniawska, La narrazione nelle scienze sociali, I edizione italiana a cura di L.M. Sicca, F. Piro, I. Boncori, 2018.

47. F. Longobardi, Le affinità del lessico, 2018.

48. G. Calogero, L'abbiccì della democrazia. E altri scritti, a cura di R. Trombelli, con una testimonianza di G. Sasso, 2018.

49. V. Fiorelli (a cura di) ${ }^{\mathrm{x} v}$, Margini e confini. Attraversamenti di metodi e linguaggi tra comunicazione, didattica e possibilità della ricerca (con prefazione di L. d'Alessandro), 2018.

50. G. Cundari, Il mondo: una bella prigione? Riflessioni geografiche, 2018.

51. M. Nicotra, Il canto dei sireni. Invenzioni trans/singolari e psicoanalisi lacaniana (con prefazione di A. Vicens e postfazione di P. Guazzo), 2019.

xwv Con scritti di Maura Striano, Rosaria Capobianco e Maria Rita Petitti, Francesco Piro, Roberta Gimigliano, Monica Mollo, Gerarda Fattoruso, Maria Incoronata Fredella, Maria Grazia Olivieri, Massimo Squillante e Antonia Travaglione, Pietro Maturi, Fabio Maria Risolo, Luca Marano, Luigi Maria Sicca, Giuseppe Recinto, Mario Nicodemi, Chiara Mallozzi e Luigi Marolda, Luigi Proserpio, Davide Bizjak, Paolo Canonico, Stefano Consiglio, Ernesto De Nito e Teresa Anna Rita Gentile, Natascia Villani.

xv Con scritti di Giuliano Amato, Gianluca Bocchi, Massimo Abdallah Cozzolino, Diego Davide, Lucia Donsi, Amedeo Feniello, Vittoria Fiorelli, Luigi Manconi, Roberta Morosini, Gianmarco Pisa, Ciro Pizzo, Leopoldo Repola, Stefano Rodotà, Francesco Varanini. 
52. L. Marano, Come parlano i giovani. Una indagine di sociolinguistica urbana (con prefazione di P. Maturi), 2019.

53. M. Floris, R. Tronci, C. Dessì, A. Dettori, Imprese familiari e imprenditorialità. La sfida del cambiamento (con prefazione di F. Cabiddu), 2019.

54. T.T. Lennerfors, L. Mitchell (eds) ${ }^{\mathrm{xv1}}$, SCOS. Searching Collectively for Our Soul, 2019.

55. Aa.Vv. ${ }^{\text {xvI }}$, Lucio Sicca. Maestri e allievi, 2019.

56. E. Sacerdote ${ }^{\mathrm{xv}}$, Breviario sul pensiero strategico. Discorsi e percorsi per conquistare il futuro migliore, 2019.

57. M.E. Santagati, L. Zan (a cura di) ${ }^{\mathrm{xix}}$, Imprenditorialità e settore museale. Esperienze e prospettive di cambiamento, 2019.

58. F.D. Perillo, D. Bizjak, L'impresa nello zaino. La Elmeco da vico San Liborio al mondo, 2019.

59. F.D. Perillo, D. Bizjak, R.A. Tundo, The Company in the Backpack. Elmeco's, from Vico San Liborio to the World, 2019.

60. M. Castro Espín ${ }^{\mathrm{xx}}$, Persone transessuali a Cuba (con prefazione di L.M. Sicca), 2019.

xvi Con scritti di Beatriz Acevedo, Omar Aktouf, Noortje van Amsterdam, Per Olof Berg, Davide Bizjak, Ilaria Boncori, Jo Brewis, Peter Case, Patricia Ehrensal, Ken Ehrensal, Hugo Gaggiotti, Silvia Gherardi, Claes Gustafsson, Campbell Jones, Nina Kivinen, Monika Kostera, Kristian J Kreiner, Thomas Taro Lennerfors, Marcus Lindahl, Steve Linstead, Tomek Ludwicki, Takashi Majima, Laura Mitchell, Albert J. Mills, Jean Helms Mills, Luc Peters, Alf Rehn, Harriet Shortt, Luigi Maria Sicca, Antonio Strati, Sam Warren, Robert Witkin, Anthony R. Yue, Peter Zackariasson.

xvi Con scritti di Luigi Guatri, Giovanni Zanetti, Adriano Giannola, Franco Amatori, Renato Mele, Francesco Testa e Riccardo Mercurio; Enzo Rullani, Paolo de Vita, Salvatore Vicari, Luigi Cantone, Pierpaolo Testa e Vincenzo Basile; Marco Ferretti, Maria Rosaria Napolitano, Francesco Izzo, Enrico Bonetti, Antonio Capaldo, Paolo Calvosa, Davide Bizjak.

хvш Con scritti di Stefano De Luca e Guido Solza.

xix Con scritti di Chiara Bombardieri, Paola Degli Esposti, Mariagabriella Fornasiero, Valentina Galloni, Alessandro Gazzotti, Claudia Giordani, Federica Guidi, Annalisa Managlia, Umberto Mossetti, Michele Recanatini, Elisa Schiavina, Stefania Spaggiari, Patrizia Tomba, Cinzia Vecchi.

xx Con scritti di Mario Bottone e Paolo Valerio; Christian Ballarin; Davide Bizjak e Cristiano Scandurra; Rossella Bonito Oliva; Giuseppe Burgio; Porpora Marcasciano; Mary Nicotra; Alessandra Riccio. 
61. G. van Wulfen, La spedizione per innovare. Un kit di strumenti visual per far partire l'innovazione (I edizione italiana a cura di M.V. Colucci, A. Forciniti, L. Migliola, L. Rossi), 2019.

62. P. Senge ${ }^{\mathrm{xx}}$, La quinta disciplina: l'arte e la pratica dell'apprendimento organizzativo (ed. 2006), (edizione italiana a cura di L.M. Sicca), 2019.

63. V. Basile, Marketing Performance Measurement in Fmcg Share of Wallet in Retailing Industry (con prefazione di L. Cantone), 2020.

64. A. Moretti, R. Tabacco, I Menuzzo e C AME. Una storia di passione per il prodotto, i clienti e le relazioni (con postfazione di R. Samiolo), 2020.

65. B. Masiello, Il lato oscuro delle reti. Strategie d'impresa e capitale sociale, (con introduzione di F. Izzo) 2020.

66. F. Izzo, B. Masiello, Le fabbriche bianche. I processi di innovazione nelle imprese creative, 2020.

67. D. Salvatore, Saperi manageriali, crescita sostenibile e sud interno. Quali contributi possono offrire gli studi di organizzazione aziendale per una crescita economica sostenibile?, 2020.

68. P. Canonico, Understanding the role of knowledge in project settings, 2020.

69. I. Boncori, T. Loughran ${ }^{\mathrm{xxI}}$, Health and Wellbeing. The University of Essex Reader (con prefazione di A. Forster), 2020.

70. J. Altmanova, L. Cannavacciuolo, M. Ottaiano, K. Russo (a cura di) ${ }^{\mathrm{xx} I I}$, Across the University. Linguaggi, narrazioni, rappresentazioni del mondo accademico, 2020.

xxi Con scritti di Luigi Maria Sicca, Edoardo Mollona e Stefano Armenia; Nicola Andreottola, Simona Capecelatro, Davide Coppola; Sergio Barile e Francesca Iandolo; Mariavittoria Cicellin e Stefano Consiglio; Corrado Cuccurullo; Davide Bizjak, Paolo Canonico e Vito Lasala; Marcello Martinez e Mario Pezzillo Iacono; Stefano Mazzoleni e Francesco Giannino; Mario Nicodemi; Francesco Perillo; Francesco Piro; Apollonia Striano.

xxı Con scritti di Anthony Forster; Ilaria Boncori and Tracey Loughran; Martyna Śliwa; Charlie V.L. Smith; Lauren O'Connell; Abby Shovlin; Peter J. Martin and Edward M. Holt; Nileema Vaswani and Ilaria Boncori; Filippo Sinicato; Jaime Lindsey; Ewen Speed, Susan McPherson and Peter Beresford; Francine Bailey; Sean Seeger.

xхп Con scritti di Augusto Guarino, Maria Laudando, Maria Alessandra Giovannini, Giovanni Rotiroti, Ruth Amar, Valeria Sperti, Andrea Pezzè, Irma Carannante, Oriana Palusci, Antonio Saccone, Germana Volpe, Laura Cannavacciuolo, Giuseppina Notaro, Fabio Rodríguez Amaya, M. Cristina Lombardi, Marco Ottaiano, Franco Paris, Francesca De Cesare, Katherine Russo, Angela Buono, Anna Mongibello, Giovanni Agresti, Jana Altmanova, Giuliana Regnoli, Rosario Gallone, Vincenzo Bavaro, Federico Pio Gentile. 
71. M.T. Como, La Sala degli Angeli nel complesso conventuale di Suor Orsola Benincasa. Per una storia della costruzione, (con prefazione di L. d'Alessandro), 2020.

72. S. Cardone, Breviario di Pedagogia Teatrale (con prefazione di A. Bergamo), 2020.

73. E. Sacerdote, Legendary brands. Valutazioni e riflessioni strategiche, 2020.

74. C. Bruno, Gestire l'industria dell'emozione. Un'analisi manageriale dell'attività dei teatri lirici (con prefazione di G. Fraquelli), 2020.

75. S. Consiglio e M. D'Isanto, La cultura che cambia (con premessa di E. D’Errico, prefazione di C. Borgomeo e postfazione di G. Volpe), 2020.

76. G. Nolfe, L.M. Sicca ${ }^{\mathrm{xxv}}$, Mobbing. Narrazioni individuali e organizzative (con prefazione di B. Czarniawska e postfazione di B. Poggio), 2020.

77. S. Armenia, The value of Systems Thinking and System Dynamics in the management of complex organizations. A selection of case studies (con prefazione di E. Mollona), 2020.

xxiv Con scritti di Giovanni Nolfe, Luigi Maria Sicca, Gemma Zontini, Christophe Dejours; Giuseppe Recinto, Raffaello Santagata de castro e Fabio Dell'Aversana, Mariapia Garavaglia; Luca Solari, Enzo Cordaro. 

Finito di stampare nel mese di ottobre 2020 dalla Vulcanica srl - Nola (NA) 